\title{
Alcázar-Palacio Arzobispal de Alcalá de Henares: pasado, presente y futuro de un Monumento Nacional en una Ciudad Patrimonio de la Humanidad
}

\author{
Abraham Consuegra Gandullo* \\ Archiepiscopal Fortress-Palace in Alcala de Henares: past, \\ present and future of a National Monument in a World Heritage \\ Site

\begin{abstract}
RESUMEN
El Alcázar Arzobispal es uno de los edificios más importantes del casco antiguo de Alcalá de Henares, declarado éste último Conjunto Histórico-Artístico desde el 10 de junio de 1968 y Patrimonio de la Humanidad desde el 2 de diciembre de 1998. El palacio se convirtió en uno de los mayores exponentes del arte medieval, renacentista, barroco y contemporáneo español, lo cual conllevó a su declaración como Monumento Nacional desde el 4 de junio de 1931. Este artículo incluye una mirada a su glorioso pasado, a su incendio y destrucción acaecida el 11 de agosto de 1939, a su posterior restauración y rehabilitación para monumento único, y a su futuro para proseguir en la tarea de recuperación con su musealización e interpretación.
\end{abstract} \\ comprobar la puesta en valor de un

\begin{abstract}
Archiepiscopal Fortress is one of the most important buildings in Alcala de Henares city centre, which was designated a Historic-Artistic Grouping in June 10, 1968, and a World Heritage Site in December 2, 1998. Palace is one of the best examples of Middle Age, Renaissance, Baroque and Contemporary Spanish Arts, which led to its designation as a National Monument in June 4, 1931. This article provides a view of its glorious past, its fire and destruction occurred on August 11, 1939, and its further restoration and renovation. It is currently an unique monument with a solid future based on the continuous efforts to turn it into a museum and provide an interpretation center.
\end{abstract}

PALABRAS CLAVE: Alcázar medieval, palacio renacentista y barroco, arzobispal, Alcalá de Henares, Archivo del Reino, incendio y destrucción, restauración y rehabilitación, musealización e interpretación.
KEY WORDS:

Middle Age fortress, Renaissance and Baroque palace, Archiepiscopal, Alcala de Henares, Kingdom's Archive, fire and destruction, restoration and renovation, museum and interpretation center.

* Diplomado en Turismo, UNED. e-mail: abrahamcg_79@ hotmail.com. 


\section{UNA MIRADA AL PASADO}

\section{Castillo-Alcázar medieval (siglos XII-XIII)}

Alcalá y su Alfoz fueron señorío de los Arzobispos de Toledo y sus Vicarios desde 1129 por donación real. Además, su condición de obispado desde tiempos visigóticos al ser lugar de martirio de los Santos Niños Justo y Pastor, determinaron a los prelados toledanos a erigir su segunda residencia en la ciudad del Henares.

Hipotéticamente, la torre y casas arzobispales remontarían sus orígenes a las prelaturas de los arzobispoa del siglo XII, siendo destruidas parcialmente en plena lucha de estas tierras entre cristianos y musulmanes, y se transformarían en el siglo XIII bajo el gobierno del prelado Ximénez de Rada (1209-1247) en una fortaleza o alcazaba posiblemente de planta cuadrangular con torreones en sus esquinas $^{1}$, al igual que el Alcázar de Toledo o el Palacio de Oriente de Madrid, y con una albacara amurallada destinada entre otros menesteres a albergar a ejércitos itinerantes o a la población en caso de peligro.

La fachada oriental del conjunto constituiría hipotéticamente la principal del castillo medieval ${ }^{2}$ al estar enfrentada a la Plazuela de la Morería ${ }^{3}$, uno de los espacios más importantes del burgo medieval y única en la que confluían los tres barrios medievales de Alcalá ${ }^{4}$. Estaría conformada por un gran arco de herradura aguda de ladrillo coronado por friso de arquillos islámicos entrelazados, tal y como era habitual en el mudéjar toledano de los siglos XIII y XIV, flanqueada por dos torres gemelas construidas con muros de tapial y ladrillo, al igual que el resto del castillo, conteniendo a su vez almenas, saeteras y ventanas con arcos de herradura.

En el interior de estos cuatro torreones y lienzos se supone que existirían diversas construcciones con diferentes salas, entre ellas la que debió de ser el embrión del famoso Salón de San Diego adosada a la crujía occidental del castillo, además de una capilla cristiana ${ }^{5}$ probablemente empotrada al muro del mismo.

En cuanto al recinto murado de la albacara, el cual se levantaría contemporáneamente al alcázar ya descrito, estaría compuesto por una muralla con torres y

\footnotetext{
1 Sobre la cual se situaría en época renacentista el llamado Patio de Columnas, ver en ARNAIZ GORROÑO, M…J.; PAVÓN MALDONADO, B.; y otros.: «Arte, arquitectura y restauraciones», Libro-guía del visitante del Palacio Arzobispal de Alcalá de Henares, Crónica de su última restauración, vol. II. Alcalá de Henares, Obispado de Alcalá de Henares, 1996, pág. 51.

2 Aunque también podría haber sido la fachada sur, al ser ambas las portadas exteriores hacia el caserío medieval, ver en LLULL PEÑALBA, J.: «La restauración del Palacio Arzobispal de Alcalá de Henares en el siglo XIX», Anuario del Departamento de Historia y Teoría del Arte UAM, vol. XIX, 2007, pág. 134.

${ }^{3}$ Hoy Patio-Plaza de Armas, Plaza de Palacio, Plaza de las Bernardas y Plaza del Padre Lecanda.

4 Aljama o judería, Almánxara o morería y Cristianería o barrio cristiano, ver en CASTILLO OREJA, M. A.: «Alcalá de Henares, una ciudad medieval en la España cristiana (s. XIII-XVI)», La Ciudad Hispánica durante los siglos XIII al XVI, vol. I, no 7, Madrid, 1985.

5 Tal y como puede constatarse en los contemporáneos castillos de Brihuega en Guadalajara o de Segura de la Sierra en Jaén, ver en PAVON MALDONADO, B.: Alcalá de Henares medieval: arte islámico y mudéjar, Madrid, CSIC, 1982, pág. 149.
} 
lienzos posiblemente almenados al norte y al oeste precedida hipotéticamente para su mejor defensa por una barbacana y cava de agua ${ }^{6}$, siendo sus torreones principales la Puerta de Burgos (Fig. 1), la Torre Albarrana «Pentagonal», la Torre "Semicircular» y la Puerta de Madrid, cerrándose al sur y al este por sendas tapias hasta enlazar con la fortaleza. En la explanada interior del recinto se irían construyendo durante la edad media, un camino de ronda empedrado con una serie de habitaciones adosadas al mismo y a la propia muralla conformando caballerizas y cuerpos de guardia para la defensa de la misma ${ }^{7}$, y a medida que la albacara fue progresivamente aprovechada como huerta, norias agrícolas a tracción animal además de aljibes con sus correspondientes canalizaciones ${ }^{8}$.

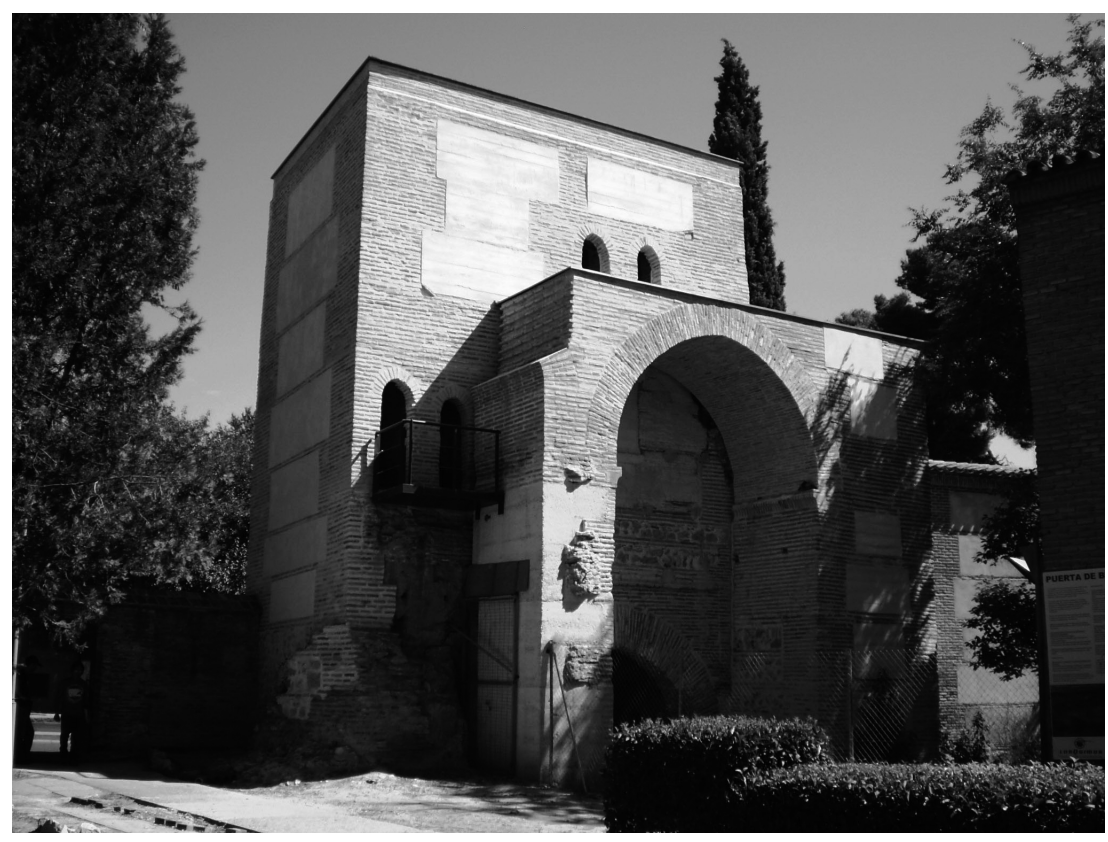

Figura 1. Torreón de la Puerta de Burgos (Foto de Abraham Consuegra Gandullo).

Como muestra de la importancia que el Alcázar Arzobispal fue adquiriendo en esta época fundacional, estaría la celebración entre sus muros de sínodos y concilios provinciales y nacionales, así como su utilización por los Reyes de Castilla como corte itinerante en sus diferentes estancias en Alcalá, con la histórica recepción de Sancho IV a Guzmán «El Bueno» en 1295 tras su heroico comportamiento en Tarifa.

\footnotetext{
${ }^{6}$ En parte originaria en arroyos naturales, pues la orografía de Alcalá en aquel tiempo sería muy distinta a la actual.

7 Descubiertas en recientes excavaciones arqueológicas al sur del recinto murado.

8 Conservadas hoy en el interior de la huerta y pudiendo ver diorama de noria en el Centro de Interpretación del Burgo de Sant Yuste-Alcalá medieval.
} 


\section{Alcázar-Palacio medieval (siglos XIV-XV)}

Bajo el gobierno del arzobispo Tenorio (1377-1399) tendría lugar la transformación del primitivo castillo en suntuoso palacio medieval. El conjunto monumental se iría desarrollando en torno a cuatro espacios correspondientes a los futuros patios de épocas renacentista y barroca ${ }^{9}$. Aunque dibujado con cierta asimetría, el edificio dejaría ver una cruz de brazos con dimensiones parecidas entre los que se desarrollarían los cuatro claustros antes mencionados, y que como consecuencia directa del carácter fortificado que tendría en sus orígenes, así como en esta otra época, serían las torres defensivas las que marcarían sus ángulos (Fig. 8).

Los patios serían en orden hipotético cronológico» de construcción:

1․ El patio del alcázar primitivo o antiguo Patio de Armas, delimitado en sus esquinas por las cuatro torres del originario edificio ya descrito. Posiblemente, en este periodo comenzaría en este espacio la construcción de un claustro mudéjar medieval ${ }^{10}$.

$2^{\circ}$. El nuevo Patio-Plaza de Armas, que se desarrollaría al este del primitivo castillo, delimitado por los torreones gemelos de la fachada oriental del anterior más otras tres torres. Hablo del Torreón de la Fuente, que estuvo adosado a la alcazaba; del Torreón de Tenorio (Fig. 2) que por su ubicación bien podría haber sido casi una torre albarrana; y el tercero, transformado posteriormente en el Torreón del Ochavo. Estas dos últimas marcarían las nuevas esquinas orientales del conjunto prelaticio, unidas ambas por una muralla de ladrillo y tapial con saeteras, típica de la época medieval que tratamos. En su interior y adosada al lienzo antes indicado, estaría la nueva capilla ${ }^{11}$ del palacio en tiempos de Tenorio, sustituta probablemente del anterior templo de Ximénez de Rada.

3․ Al norte del anterior patio se desarrollaría un nuevo espacio, que con el paso del tiempo llegaría a ser el maravilloso Claustro Renacentista del Aleluya.

4․ $\quad$ Y el Patio de la Fuente, delimitado por los dos torreones de la fachada norte del primitivo alcázar, más otras dos torres unidas por su correspondiente lienzo murado a septentrión de la anterior.

Pero Tenorio no sólo ampliaría el castillo, sino que también modificaría el recinto murado de la albacara utilizando para ello piedras y lápidas procedentes de las ruinas de la Alcalá Romana o Complutum ${ }^{12}$, adecentando sus tramos norte y

9 Recordando en parte a los Hospitales de Santiago, Granada o Todelo y de alguna manera incluso al Monasterio de El Escorial.

10 ARNAIZ GORROÑO, Mạ.J.; PAVÓN MALDONADO, B.; y otros.: «Arte, arquitectura y...», Op. Cit., pág. 57.

${ }_{11}$ Embrión del suntuoso Salón de Concilios.

12 Tal y como hoy puede observarse en los Torreones de la Fuente y de Tenorio. 
Alcázar-Palacio Arzobispal de Alcalá de Henares: pasado, presente y futuro...

oeste ya existentes, y levantando igualmente sobre la tapia sur una nueva muralla desde la Puerta de Madrid hasta el Palacio ${ }^{13}$. De entre los nuevos torreones de ésta destacaría la ojival Puerta de la Albacara, construida para comunicar el caserío medieval de Alcalá con el recinto interior del alcázar.

Las ampliaciones continuarían en los episcopados de Martínez de Contreras (1423-1434) y de Juan de Cerezuela (1434-1442), bajo los cuales se construirían, tal y como atestiguan los escudos de Contreras sitos en la fachada oriental del edificio, el Salón de Concilios, con un maravilloso artesonado policromado y yeserías gótico-mudéjares en sus muros, constituyéndose desde entonces como la sala principal para acontecimientos en el palacio, y contiguo al anterior y bajo el característico cimborrio octogonal del Torreón del Ochavo (Fig. 10) el Antesalón de Concilios, con otro artesonado mudéjar con yeserías donde campeaban los escudos de armas de Cerezuela. En la planta baja de la misma ala se construiría igualmente el Salón de Isabel la Católica (Fig. 7), el cual contendría otro magnífico artesonado, además de frisos y nuevamente blasones del arzobispo Contreras.

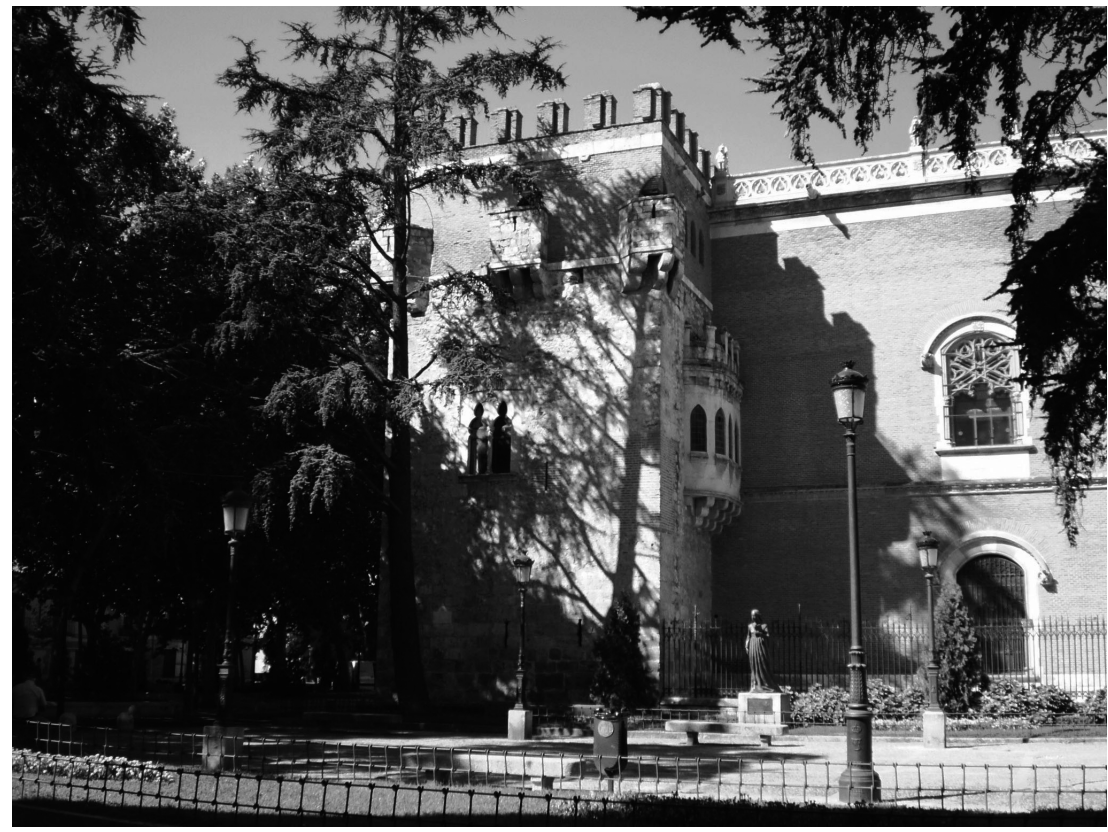

Figura 2. Torreón de Tenorio (Foto de Abraham Consuegra Gandullo).

Hipotéticamente por esta misma época, se terminaría el claustro de estilo mudéjar con pilares de ladrillo y pies derechos de madera del viejo patio del castillo medieval, tal y como atestiguarían igualmente los escudos pintados y ya desaparecidos en las tabicas de los techos planos de su galería baja.

${ }^{13}$ ARNAIZ GORROÑO, Ma. J.; PAVÓN MALDONADO, B.; y otros.: Op. Cit., pág. 50. 
A finales del siglo $\mathrm{XV}$, seguirían realizándose modificaciones bajo los episcopados de Carrillo de Acuña (1446-1482), quién intervendría nuevamente en la Puerta de Burgos hacia el año 1476, de Mendoza (1482-1495) y del Cardenal Cisneros (1495-1517), una de las figuras más importantes en la historia de Alcalá y de España, quién reformaría el Salón de San Diego, tal y como atestiguaban sus escudos de armas sitos en el friso de su artesonado ${ }^{14}$, además del aderezamiento general del palacio bajo la dirección del alarife morisco Yucaf-Yusuf-Orejuno.

Durante la transformación de alcázar en palacio medieval acaecerían en el mismo numerosos acontecimientos históricos, entre ellos la celebración de las Cortes de Castilla en 1348, en las que Alfonso XI derogó el Fuero Juzgo Visigótico proclamando el famoso Ordenamiento de Alcalá; también aquí encontraría la muerte el Rey Juan I como consecuencia de una caída del caballo que montaba en las inmediaciones de la Puerta de Burgos; además, durante una de las estancias de los Reyes Católicos entre sus muros nacería en 1485 la infanta Catalina de Aragón, quién llegó a ser Reina de Inglaterra al casarse con Enrique VIII; poco después, el 20 de febrero de 1486 la Reina Isabel la Católica recibiría en audiencia por primera vez al navegante Cristóbal Colón, posiblemente en el ya citado Salón de San Diego (o incluso en el de Concilios o el de Isabel la Católica), celebrándose la primera entrevista que conllevaría años después al Descubrimiento de América; y también en el palacio alcalaíno daría a luz la infortunada Reina Juana «la loca» en 1503 a Fernando, hermano de Carlos $\mathrm{V}$ y futuro Emperador de Alemania ${ }^{15}$.

\section{Palacio Renacentista (siglos XV-XVI)}

Sería durante el siglo XVI, cuando el Alcázar Arzobispal de Alcalá alcanzaría su máximo esplendor artístico hasta conformar uno de los mayores conjuntos monumentales renacentistas de España. La obra primeriza del arzobispo Fonseca (1524-1534), bajo la dirección del arquitecto Alonso de Covarrubias y del escultor Alonso Berruguete, sería la transformación del ala norte del Patio de Armas de época de Tenorio con la construcción de su nueva fachada plateresca (Fig. 10), tal y como atestiguan los blasones del mencionado prelado sitos en la misma, erigiéndose desde entonces como la portada principal del Palacio ${ }^{16}$. Construida en sillarejo y dividida en dos plantas, albergaba en la baja la Contaduría Mayor del Obispado, tal y como reflejan los letreros esculpidos en los dinteles de sus huecos; en planta alta contenía ventanas, estando la central del conjunto adornada por el escudo imperial de Carlos $\mathrm{V}$; además, la fachada contiene una galería superior con arcos de medio punto sobre columnas jónicas, típica de la época en estudio y que

\footnotetext{
14 Realizado en estilo Cisneriano al igual que los artesonados del Paraninfo y de la Capilla de San IIdefonso de la Universidad de Alcalá.

${ }^{15}$ ARNAIZ GORROÑO, Ma. J.; PAVÓN MALDONADO, B.; y otros.: «Arte, arquitectura y...», Op. Cit., págs. 7-242-243.

16 Y guardando una gran semejanza con algunas de las fachadas del Alcázar de Toledo.
} 
Alcázar-Palacio Arzobispal de Alcalá de Henares: pasado, presente y futuro...

se repetiría en el ático de otro de los monumentos más insignes de la ciudad complutense, la portada de la Universidad Cisneriana.

En el Patio del Aleluya, Covarrubias trazaría una rica crujía de once arcos y doce columnas de piedra repetidos en planta superior, ambas con una riqueza decorativa extraordinaria, con balaustrada goticista y enjutas con los escudos de Fonseca. El extremo oriental de esas dos galerías de arcos estaría rematada por una excelente portada plateresca, conteniendo igualmente entre toda su decoración emblemas de los prelados Fonseca y Tavera.

Sobre el Patio de Armas de Ximénez de Rada y claustro mudéjar en prelaturas siguientes, Covarrubias y Berruguete levantarían el Patio de Fonseca o de las Columnas (Figs. 3, 5 y 8) y su Escalera de Honor. El claustro renacentista tenía planta ligeramente rectangular, formado por un total de 76 columnas de piedra con capiteles clásicos sobre los que cargaban en galería baja arcos de medio punto con blasones de Fonseca en sus enjutas, y en galería alta, piso adintelado con zapatas de tradición hispana y balaustrada gótica con abundante decoración. La escalera $^{17}$ se construiría bajo el gobierno del arzobispo Tavera (1534-1545), de tipo claustral típicamente española con tres tramos en caja cuadrada abierta, conteniendo 253 sillares de piedra ricamente labrada y cubierta por un fastuoso artesonado. Ambas, patio y escalera, eran piezas fundamentales del arte plateresco castellano y verdadero broche de oro del palacio alcalaíno.

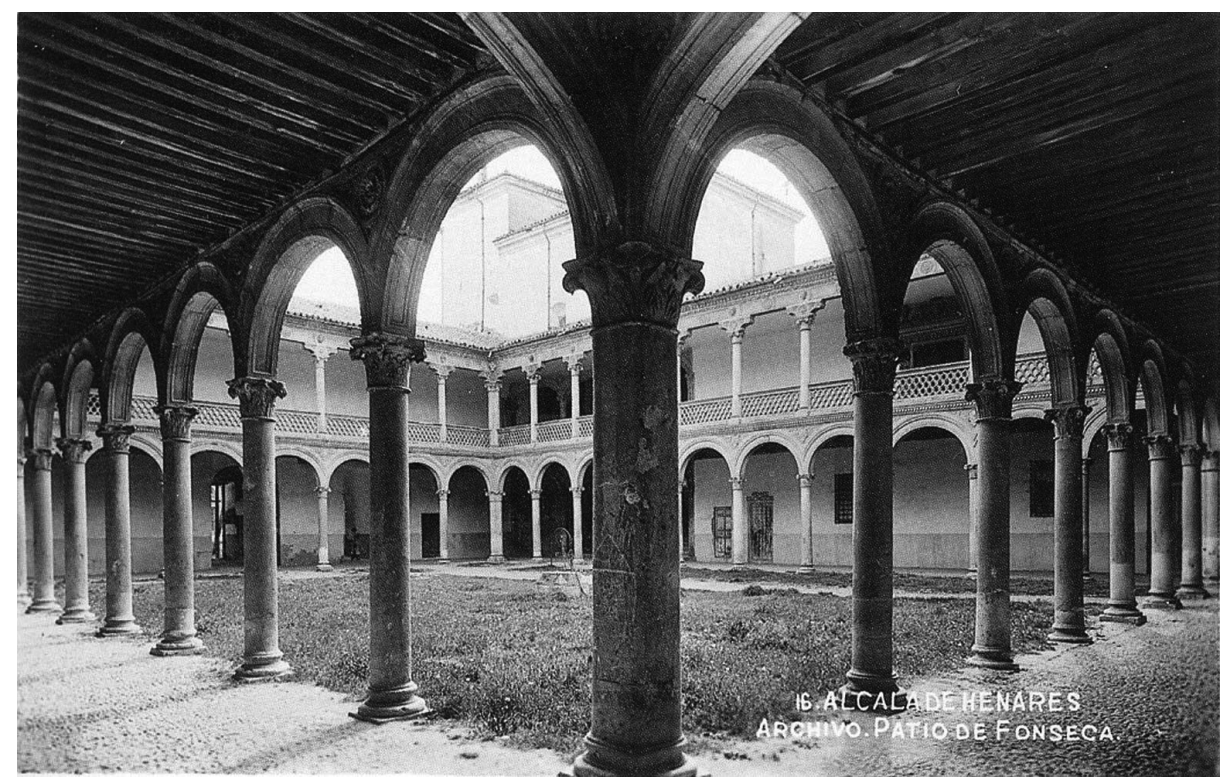

Figura 3. Desaparecido Patio de Fonseca o de las Columnas (Foto de Hauser y Menet).

17 Gemela de la del Hospital de Santa Cruz de Toledo, aunque con mayor riqueza ornamental. 
En el ala sur del primitivo castillo medieval, el arquitecto Alonso de Covarrubias levantaría también bajo la prelatura de Fonseca, tal y como atestiguaban sus escudos de armas, una soberbia fachada con galerías «como loggias abiertas a cuidados jardines». Esta portada, Ilamada del Mediodía o del Ave María (Figs. 4 y 5), estaría compuesta por 31 pilastras en planta baja sobre las que descansarían arcos de medio punto, y con otras 31 columnas de piedra en planta alta bajo arcos rebajados. La fachada le confería «una nota de exterior interiorizado» al palacio, provocada por su doble arquería y por las dos elegantes torrecillas, construidas en esta época por el arquitecto mayor de Burgos José de la Peña, formadas por lindos templetes coronadas por sendos chapiteles de pizarra. Esta portada, que siempre habría estado abierta directamente al caserío medieval, sería cercada con un muro de tapial y ladrillo durante el episcopado de Tavera, diseñando en su espacio interior el renacentista Jardín de la Noguera o del Vicario (Fig. 4).

Y ya en el Patio de la Fuente se construirían, seguramente también en el siglo $\mathrm{XVI}$ y bajo proyecto de Covarrubias, las crujías oeste, sur y este formadas por una doble galería de arcos de medio punto sobre 82 columnas de piedra, quedando la crujía norte cerrada probablemente por una tapia o muralla medieval que unía los dos torreones que marcaban las esquinas del mismo. En el centro del claustro, posiblemente ajardinado, se situaría una pila o fuente de la que derivó su nombre ${ }^{18}$ (Fig. 8).

Poco antes de 1567, se llevaría a cabo igualmente el remate superior del medieval Torreón de Tenorio con un alto chapitel de pizarra de parecida factura a los anteriormente citados de la Fachada del Mediodía, en el cual se colocó el llamado Reloj de Palacio, siendo denominado también desde entonces como la Torre del Reloj ${ }^{19}$ (Figs. 4 y 5).

Pero no sólo las fachadas o los patios serían ricamente reconstruidos durante el siglo XVI, pues también sus salas interiores se decorarían con nuevos artesonados, solerías, azulejos, zócalos y otras obras de arte como pinturas y cuadros, esculturas, estanterías, libros para su maravillosa biblioteca... conformando unos interiores de claro signo palaciego.

Igualmente, en esta época el palacio sería visitado en diversas ocasiones por los Reyes y su familia. Precisamente durante una de esas estancias en 1562 el infortunado Príncipe Carlos, hijo de Felipe II, sufriría una grave caída por una escalera al perseguir a una doncella empeorándose aún más su ya delicada salud ${ }^{20}$.

18 ARNAIZ GORROÑO, Mํ. J.; PAVÓN MALDONADO, B.; y otros.: «Arte, arquitectura y...», Op. Cit., pág. 77

19 LLULL PEÑALBA, J.: «La restauración del Palacio...», Op. Cit., pág. 137.

20 ARNAIZ GORROÑO, Mํ. J.; PAVÓN MALDONADO, B.; y otros.: «Arte, arquitectura y...», Op. Cit., pág. 8. 


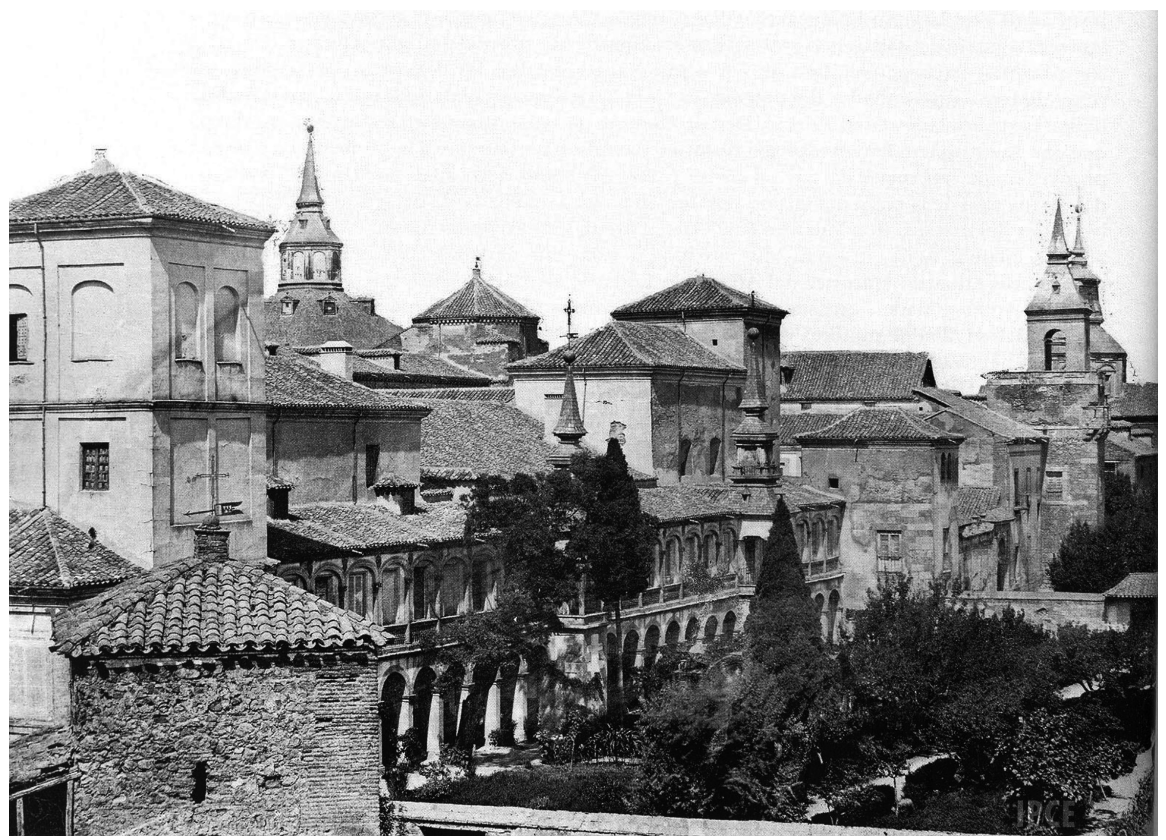

Figura 4. Desaparecido conjunto monumental (Foto de J. Laurent).

\section{Palacio Barroco (siglos XVII-XVIII)}

Bajo el gobierno de Sandoval y Rojas (1599-1618), se llevarían a cabo grandes modificaciones en las inmediaciones del palacio, en especial en su sector noreste con la construcción del aledaño Monasterio de San Bernardo. Para su edificación se procedió a la demolición del vecino barrio de la morería medieval de la Almánxara, creando la Plaza de las Bernardas como espacio diáfano para la contemplación del nuevo cenobio y del ala oriental del palacio. Además, la medieval Puerta de Burgos quedó tapiada dentro de la huerta del citado convento, perdiendo así el carácter de poterna al caserío alcalaíno ${ }^{21}$, cumpliendo desde 1618 la función de puerta norte de la villa el nuevo Arco de San Bernardo.

En la prelatura de Pascual de Aragón (1666-1677), se intervendría en los jardines del palacio, en especial en el ya citado Jardín de la Noguera, conjugando sus trazas renacentistas con las barrocas. Bajo la del Cardenal-Infante de Borbón (1735-1754), hijo de Felipe $\mathrm{V}$ y hermano de Carlos III, se llevó a cabo la sustitución del escudo imperial de Carlos $V$ de la fachada plateresca por el barroco y gran escudo de los Borbones, reemplazando para ello la ventana central por un balcón volado (Fig. 9).

21 Y siendo utilizada a partir de ese momento como capilla, ver en GÓMEZ LÓPEZ, C.: El urbanismo de Alcalá de Henares en los siglos XVI y XVII: EI planteamiento de una idea de ciudad, Madrid, Estudios de la UNED, 1998, págs. 63-206-221. 


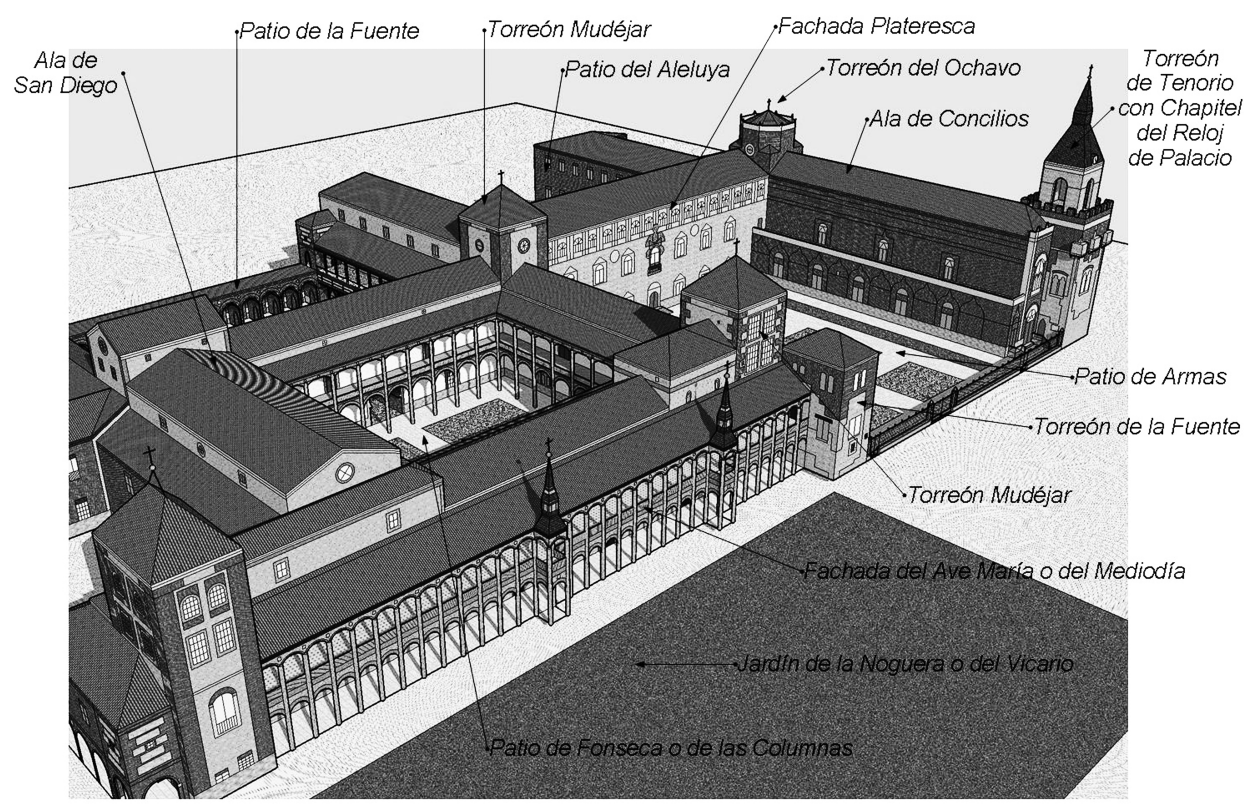

Figura 5. Recreación virtual del desaparecido palacio (Dibujo de Abraham Consuegra Gandullo).

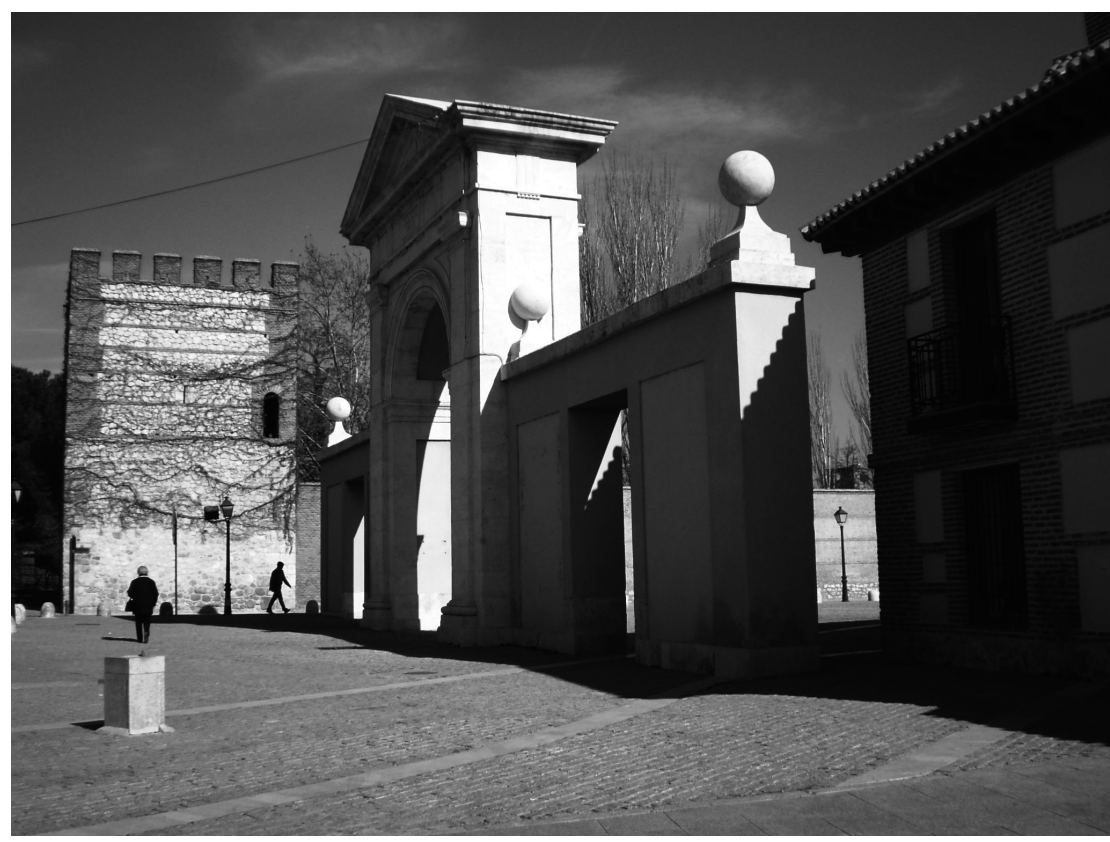

Figura 6. Torreón y Puerta de Madrid (Foto de Abraham Consuegra Gandullo). 
Alcázar-Palacio Arzobispal de Alcalá de Henares: pasado, presente y futuro...

Y durante el pontificado del Cardenal Lorenzana (1772-1800) se procedió a la sustitución de la medieval Puerta de Madrid por una nueva poterna monumental de estilo Neoclásico claramente inspirada en la Puerta de Alcalá madrileña (Fig. 6).

Como apuntes históricos, destacar que en este periodo también habría visitas regias al palacio, como las que protagonizara Felipe $\mathrm{V}$ a finales del siglo XVII e inicios del XVIII, señalando igualmente que sería utilizado como gran residencia, alojándose en el mismo desde un gran número de sacerdotes refugiados por la Revolución Francesa ${ }^{22}$ hasta ilustres caballeros que estudiaban en la afamada Universidad Complutense.

\section{De Palacio Arzobispal a Archivo General Central del Reino (siglos XIX-XX)}

En la prelatura del infante arzobispo Luis María de Borbón (1800-1823), se produjo la invasión de España por tropas napoleónicas conllevando a la Guerra de la Independencia, la cual produjo graves deterioros en el palacio. Se destruyeron gran parte de su valioso mobiliario, biblioteca y ornamentación de sus salas, debido a que tanto el ejército francés como el español lo utilizaron como cuartel.

El edificio sufriría igualmente las consecuencias de las Desamortizaciones de Mendizábal y Espartero en los años 1835 y 1841, respectivamente. En propiedad del Estado, saldría a subasta pública sin que se encontrara comprador, pensándose entonces en utilizarlo como sede de la Academia de Artillería, pero en virtud del Concordato de 1851 el palacio volvió a propiedad de la Iglesia. Con la nueva Desamortización de Madoz en 1855 volvería a utilizarse como cuartel, hasta que finalmente y bajo la prelatura del arzobispo Cirilo Alameda y Brea (1857-1872) y por Real Decreto de 17 de julio de 1858, se creó para instalarlo en el antiguo alcázar alcalaíno el Archivo General Central del Reino como alivio al sito en Simancas, otorgándose la cesión el 2 de marzo de 1859, destinando una parte a archivo reservándose el prelado otra parte del mismo.

En general, tal y como correspondía con la segunda mitad del siglo XIX, los principios teóricos aplicados en las grandes y no poco controvertidas obras de restauración realizadas en el conjunto palacial para su adecuación en Archivo, se basaron en la recreación de la unidad estilística del monumento, la cual no sólo buscaba la rehabilitación funcional del edificio sino recuperar su forma prístina u original ${ }^{23}$. Por diversas razones, no tuvieron la continuidad adecuada dilatándose

22 ARNAIZ GORROÑO, Mำ. J.; PAVÓN MALDONADO, B.; y otros.: «Arte, arquitectura y...», Op. Cit., pág. 108.

${ }_{23}$ Criterios defendidos por Viollet-le-Duc con la llamada restauración «en estilo», ver en LLULL PEÑALBA, J.: «La destrucción del patrimonio arquitectónico de Alcalá de Henares (1808-1939)», Monografías Humanidades de la Universidad de Alcalá, Alcalá de Henares, UAH, 2006, págs. 354-392; GONZÁLEZ-VARAS IBÁÑEZ, I.: Conservación de bienes culturales: teoría, historia, principios y normas, Madrid, Cátedra, 1999, pág. 155. 
durante muchos años, con los consiguientes cambios de criterio acerca del sentido de las distintas restauraciones que se llevaron a cabo.

En 1859, las obras comenzarían asumidas por el Ministerio de Fomento y supervisadas por la Academia de San Fernando, bajo la dirección del arquitecto Juan José de Urquijo, siendo el primer jefe del archivo recién creado Francisco González Vera, prolongándose éstas hasta el año 1900 aproximadamente e interviniendo en ellas otros arquitectos, así como los artistas Manuel Laredo y Pedro Nicoli24.

Las principales intervenciones, entre otras varias fueron, la declaración de ruina y demolición en 1863 por Urquijo de la fastuosa arquería del Patio del Aleluya, pendiéndose de esta manera la galería renacentista con mayor influencia italiana del conjunto. Hacia 1875 y hasta la primera década del siglo XX, se llevarían a cabo las nuevas edificaciones noroccidentales de ampliación del palacio a cargo del arquitecto Heredia Tejada, destacando entre ellas el Torreón del Archivo (Fig. 8).

En 1878 se acometerían controvertidas restauraciones en el Salón de Concilios por los artistas Laredo y Nicoli, interviniendo en sus yeserías y en la decoración del artesonado con la recuperación de sus policromías, recreando elementos desaparecidos "con motivos de época». Igualmente se reformarían las fachadas del ala de Concilios, revistiéndolas con ladrillo en estilos Neomudéjar y Neogótico.

Manuel Laredo también restauraría hacia 1880 el artesonado del Salón de San Diego, descubriendo los escudos de Cisneros en su friso y decorando un nuevo techo inspirado en la Capilla de San Ildefonso de la Universidad Complutense alcalaína ${ }^{25}$. Contemporáneamente, se levantaría además una vistosa verja diseñada por Urquijo y fundida en Bélgica, como nuevo cierre del Patio de Armas con el propósito de ofrecer una mejor vista de su fachada Plateresca.

Como inciso, citar que en el año 1885 se crearía el nuevo Obispado Madrid-Alcalá, poniendo así fin a siglos de gobierno del episcopado toledano en la iglesia alcalaína, siendo el prelado Fray Ceferino González quien renunciara a sus posesiones en el Palacio Arzobispal, pasando a pertenecer íntegramente al Archivo del Reino.

En 1892, el arquitecto Arturo Calvo llevó a cabo la restauración del Torreón de Tenorio con la demolición de la Torre del Reloj, reconstruyendo sus almenas y añadiendo un balcón a la Plaza de las Bernardas. Tras intervenir sobre el resto de la muralla y cegar su «cava» para urbanizar las rondas de la ciudad, el proceso principal de restauración y rehabilitación para sede del Archivo se consideraría concluido.

En cuanto al contenido del Archivo, citar que custodiaba los documentos producidos por la Administración General del Estado una vez hubiera finalizado su trami-

\footnotetext{
24 ARNAIZ GORROÑO, Mํ. J.; PAVÓN MALDONADO, B.; y otros.: «Arte, arquitectura y...», Op. Cit., págs. 115-116.; LLULL PEÑALBA, J.: Op. Cit., pág. 391.

${ }^{25}$ Estando la citada institución ya cerrada y trasladada a Madrid desde el año 1836.
} 
Alcázar-Palacio Arzobispal de Alcalá de Henares: pasado, presente y futuro...

tación y consulta. A mediados de la década de 1930, contenía alrededor de 150.000 legajos ubicados en más de 76 salas del palacio (Fig. 7) y organizados en cuatro secciones: Clero, con la documentación producida por la Iglesia Magistral de Alcalá entre los siglos XVI y XVIII; Ministerios, con los fondos documentales de las carteras de Fomento, Gobernación, Guerra, Hacienda y Presidencia, datados entre los siglos XVI y XIX; Tribunal de Cuentas, con toda la documentación fiscal y económica del Estado desde el periodo medieval hasta el siglo XX, abarcando no sólo a los territorios peninsulares e insulares sino también a los ultramarinos de América, África y Filipinas; y finalmente, los Protocolos Notariales de Alcalá de Henares ${ }^{26}$.

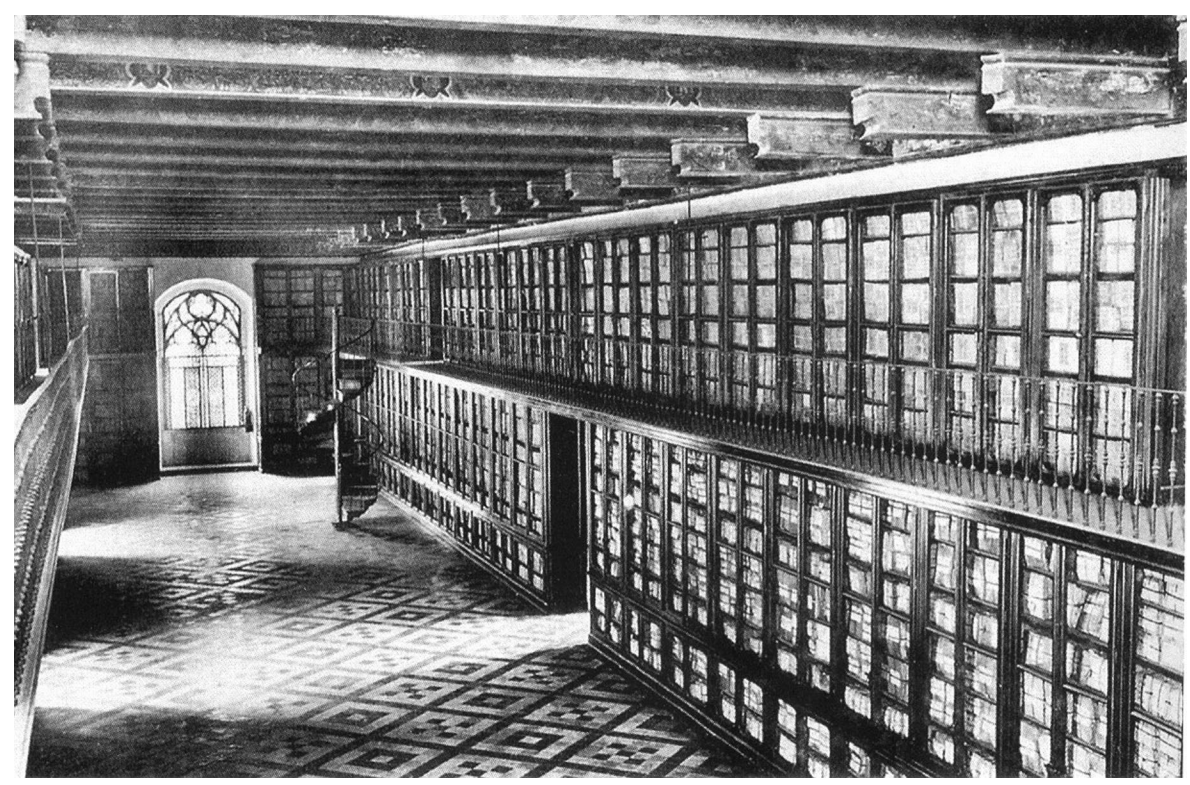

Figura 7. Desaparecido Salón de Isabel la Católica (Foto de Postal S.N.).

Además, en el Salón de San Diego se custodiaban, entre otras joyas documentales, autógrafos de monarcas y príncipes de España, el original de la abdicación de Felipe V, cartas familiares de la Casa Real Española, las primeras constituciones de la Universidad Complutense con firma original del Cardenal Cisneros y un memorial autógrafo del ilustre alcalaíno y genio de las letras castellanas Miguel de Cervantes ${ }^{27}$.

Aparte del Archivo, el palacio contenía otras joyas como la Biblioteca, que a pesar de haber sufrido pérdidas incalculables a lo largo de su historia, seguía conte-

26 Además, alojó temporalmente una serie de fondos históricos del Antiguo Régimen de los tribunales de la Inquisición de Toledo y Valencia, la Cámara de Castilla, la Secretaría de Estado y parte de los documentos de la Universidad Complutense, ver en SAN LUCIANO, J. Mํㅡ.: El incendio y destrucción del Archivo General Central. Alcalá de Henares 1939, España, Ediciones Lema y Librería Domiduca, 2009, págs. 34-51.

27 SAN LUCIANO, J. Ma․: El incendio y destrucción..., Op. Cit., pág. 57. 
niendo un nutrido fondo bibliográfico de más de 8000 volúmenes, con un ejemplar completo de la Biblia Políglota Complutense entre ellos ${ }^{28}$, además de 500 folletos y más de 30 planos y mapas.

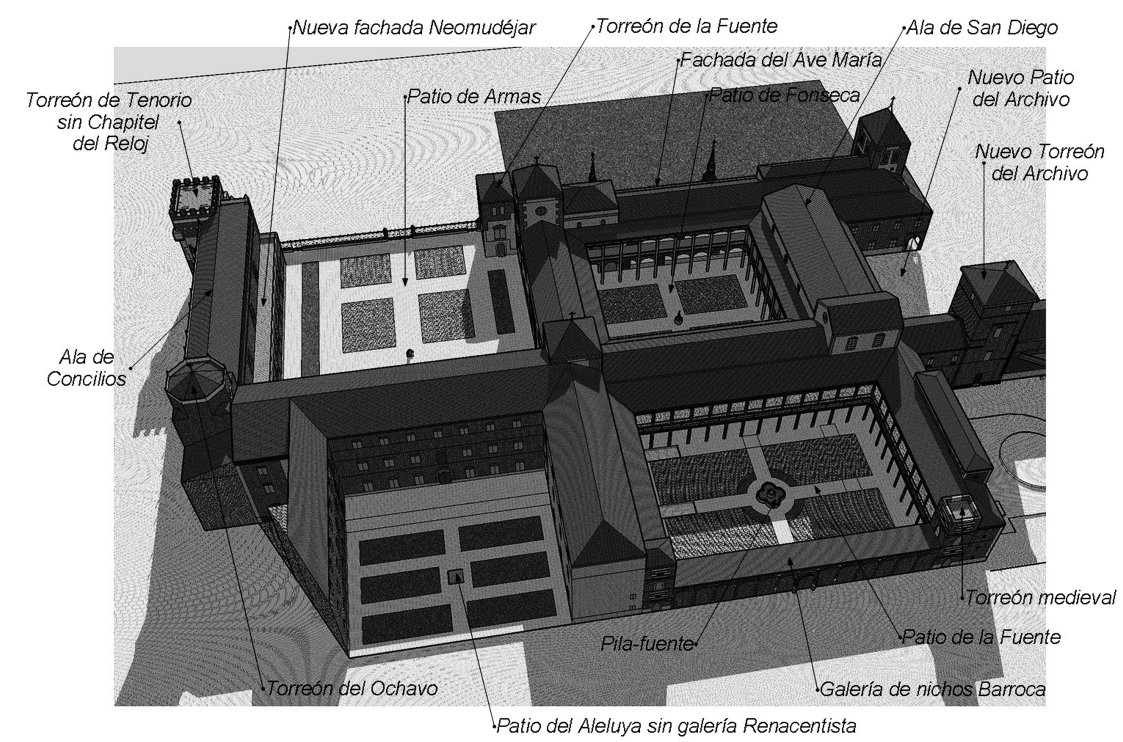

Figura 8. Recreación virtual del desaparecido archivo (Dibujo de Abraham Consuegra Gandullo).

Albergaba el Museo Arqueológico Complutense, promovido por Escudero de la Peña como jefe del archivo alcalaíno (1875-1883) ${ }^{29}$, mostrando elementos del Palacio que ya no estaban emplazados en su ubicación original ${ }^{30}$, restos del desaparecido y también alcalaíno Monasterio Franciscano de San Diego ${ }^{31}$, piezas arqueológicas de la Ciudad Romana de Complutum...

Contenía igualmente una riquísima Colección de Pesas y Medidas procedentes de todo el país, constituyendo una museografía única en España, además de obras de arte pictóricas como los frescos realizados por Juan Correa de Vivar en la capilla arzobispal o varios cuadros, de entre ellos a destacar "La comunión de Santa María Egipciaca» de Francisco Camilo.

Por último, destacar otro de los hechos históricos que ocurrió en el palacio en esta época, como uno de los más importantes en la historia contemporánea de Alcalá de Henares, pues el 28 de octubre de 1850 vería la luz en el Alcázar Arzo-

\footnotetext{
28 Ídem, pág. 38.

29 Y creador de uno de los mejores monográficos sobre el Alcázar Arzobispal de Alcalá, ver en SAN LUCIANO, J. Ma․: Op. Cit., pág. 27.

30 Como los restos de la demolida galería renacentista del Patio del Aleluya.

${ }^{31}$ Edificio gótico de los siglos XIII-XV, demolido a mediados del siglo XIX para construir sobre su solar el Cuartel del Príncipe, y del que se han encontrado recientemente restos arqueológicos en las obras de adecuación del inmueble en Biblioteca Central de la Universidad de Alcalá.
} 
Alcázar-Palacio Arzobispal de Alcalá de Henares: pasado, presente y futuro...

bispal el origen de la primera sociedad particular que se creó en España para salvar y conservar filantrópicamente un patrimonio monumental y artístico: «La Sociedad de Condueños de los Edificios que fueron Universidad». Originada por iniciativa propia de un gran número de vecinos de la ciudad alcalaína, con distintas ideas políticas, posiciones sociales y profesiones, pero compartiendo una idea común, la de librar del expolio y destrucción el antiguo edificio de la Universidad Complutense del Cardenal Cisneros. El ya citado día, se reunieron en el palacio surgiendo una comisión compuesta entre otros por el arzobispo de Toledo Juan José Bonell Orbe, la cual se encargó de realizar ante las autoridades pertinentes todas las gestiones necesarias para, dentro de la legalidad vigente, recuperar la propiedad de la antigua Universidad. Finalmente, ésta sería comprada y adquirida el 12 de diciembre de 1850, firmándose el 12 de enero de 1851 ante el notario de la ciudad complutense Gregorio Azaña ${ }^{32}$, la escritura de constitución de la Sociedad de Condueños ${ }^{33}$.

\section{Incendio y destrucción del Archivo General Central del Reino (siglo XX)}

En el primer tercio del siglo $\mathrm{XX}$, acaecieron las declaraciones de reconocimiento y protección del legado artístico de los edificios estudiados en este artículo. El Ministerio de Instrucción Pública y Bellas Artes declaró la Portada Plateresca de la antigua galería del Aleluya y el Monasterio de San Bernardo como Monumentos Arquitectónicos-Artísticos el 25 de julio de 1922 y el 13 de enero de 1924, respectivamente, y todo el conjunto monumental del Palacio Arzobispal de Alcalá como Monumento Nacional el 4 de junio de 1931. Igualmente, al amparo de la II República tuvo lugar la promulgación de la primera gran norma de salvaguarda del Patrimonio Cultural Español en su historia, la Ley de Protección del Tesoro Artístico Nacional del año 1933, derivada de la evolución de las teorías restauradoras de la primera mitad del siglo XX, las cuales anteponían los criterios de conservación a la restauración en estilo practicada en el siglo XIX e inicios del $X^{34}$.

Visto lo anterior, se da una gran contradicción en cuanto a que fue en los años 30 del siglo pasado cuando el Alcázar fue protegido legislativamente por primera vez en materia de preservación artística y monumental, en contraposición con la militarización y mal uso que se hizo del mismo pocos años después, conllevando con ello a su incendio y destrucción.

La primera agresión que sufriría el patrimonio cultural del antiguo palacio durante esta fatídica época fue la destrucción de la corona real del escudo de la fa-

32 Abuelo de Manuel Azaña, otro de los ilustres hijos de la ciudad alcalaína y Presidente de la II República Española.

${ }^{33}$ LLULL PEÑALBA, J.: «La destrucción del patrimonio...», Op. Cit., pág. 80.; FERNÁNDEZ MAJOLERO, J.: Breve historia de la Sociedad de Condueños. Alcalá de Henares 1850-2000, Gráficas Ancora y El Corte Inglés, 2000.

34 GONZÁLEZ-VARAS IBÁÑEZ, I.: Conservación de bienes culturales: teoría..., Op. Cit., pág. 511. 
chada del Patio de Armas en el año 1931, tras la proclamación de la II República Española $^{35}$. Desde entonces y hasta el comienzo de la contienda civil en 1936, no volvería a sufrir ningún otro daño, gracias en gran parte por estar dedicado a un uso civil como era el de Archivo de la Nación ${ }^{36}$.

En el ya citado año 1936, tras el golpe de estado militar y comienzo de la Guerra Civil, el palacio con todo su componente monumental, artístico y documental incluido, sería ocupado por el ejército del bando republicano, instalando en él una base de carros de combate. Igualmente, utilizaría el aledaño Monasterio de San Bernardo como almacén de gasolina, a pesar de albergar en su interior no sólo sus propias obras de arte, sino también las de gran parte del resto de cenobios complutenses recogidas por la Junta de Incautación, Protección y Salvamento del Tesoro Artístico Español durante la contienda civil para la salvaguarda de las mismas $^{37}$. Los sucesivos bombardeos que sufriría la ciudad complutense respetaron al viejo alcázar, y a pesar del mal uso del monumento, al final de la guerra se encontraría sin desperfectos de consideración.

En el año 1939, el cual marcaría el fin del conflicto bélico, el ejército del bando nacional, vencedor de la fraticida contienda civil, continuaría también utilizándolo como base de carros de combate y depósito de armas. Ante esta delicada situación, el último Director del Archivo Carlos Martín Bosch, el catedrático Lacarra como funcionario de la Junta de Incautación y el primer Alcalde de Alcalá tras la guerra Huerta Calopa, comunicaron a las distintas autoridades de la época el peligro que representaba el más mínimo conato de incendio en un inmueble de las características del palacio. Nadie escucharía las repetidas peticiones manteniéndose la base militar, y en la tarde del 11 de agosto de 1939 el edificio comenzó a arder.

En poco tiempo el violento fuego penetraría en el interior del alcázar, primero en el taller militar, extendiéndose rápidamente por la crujía del Salón de San Diego, a los Patios de la Fuente y de Fonseca, a los salones del Mediodía y a la Escalera de Tavera, destruyendo esta zona en menos de dos horas. El incendio sería avivado cada vez más debido al inmenso bosque de maderas que componían sus artesonados, a los más de cien mil legajos de documentos que contenía y a las explosiones de la munición almacenada por los militares a medida que ésta era alcanzada por las llamas, provocando que igualmente ardieran sin remisión la Fachada Plateresca y el Ala de Concilios (Fig. 9), destruyendo incluso la cúpula del vecino Monasterio de San Bernardo. Por consiguiente, en la madrugada del 12 de agosto de 1939, el Palacio Arzobispal y su Archivo del Reino prácticamente ya no existían, perdiéndose una joya artística y documental con más de ocho siglos de antigüedad e historia en tan sólo unas pocas horas.

35 LLULL PEÑALBA, J.: «La destrucción del patrimonio...», Op. Cit., pág. 174.

${ }_{36}$ No corrieron la misma suerte otros monumentos de Alcalá como iglesias, conventos y monasterios, ver en LLULL PEÑALBA, J.: Op. Cit.

37 Ídem, pág. 194.; SAN LUCIANO, J. Ma․: El incendio y destrucción..., Op. Cit., pág. 219. 
Alcázar-Palacio Arzobispal de Alcalá de Henares: pasado, presente y futuro...

La justicia militar comenzaría a trabajar en la misma noche del fatídico 11 de agosto, con la conclusión del juez castrense Bernardino Puente de acusar como único responsable del incendio "debido a sus peligrosas travesuras» al niño de nueve años y vecino de la localidad Florentino Huertes, transfiriendo la causa a la justicia ordinaria en diciembre de 1939. Por su parte, el juez civil Vázquez de Prada no encontraría razones para imputar a nadie, después de que el niño encausado se desdijera de todo lo declarado anteriormente. En el año 1946 el expediente sería sobreseído, no figurando ninguna nota referente a este suceso en las hojas de servicio de los militares responsables de la base sita en el alcázar, pareciendo por lo tanto que este grave hecho nunca acaeciós ${ }^{38}$.

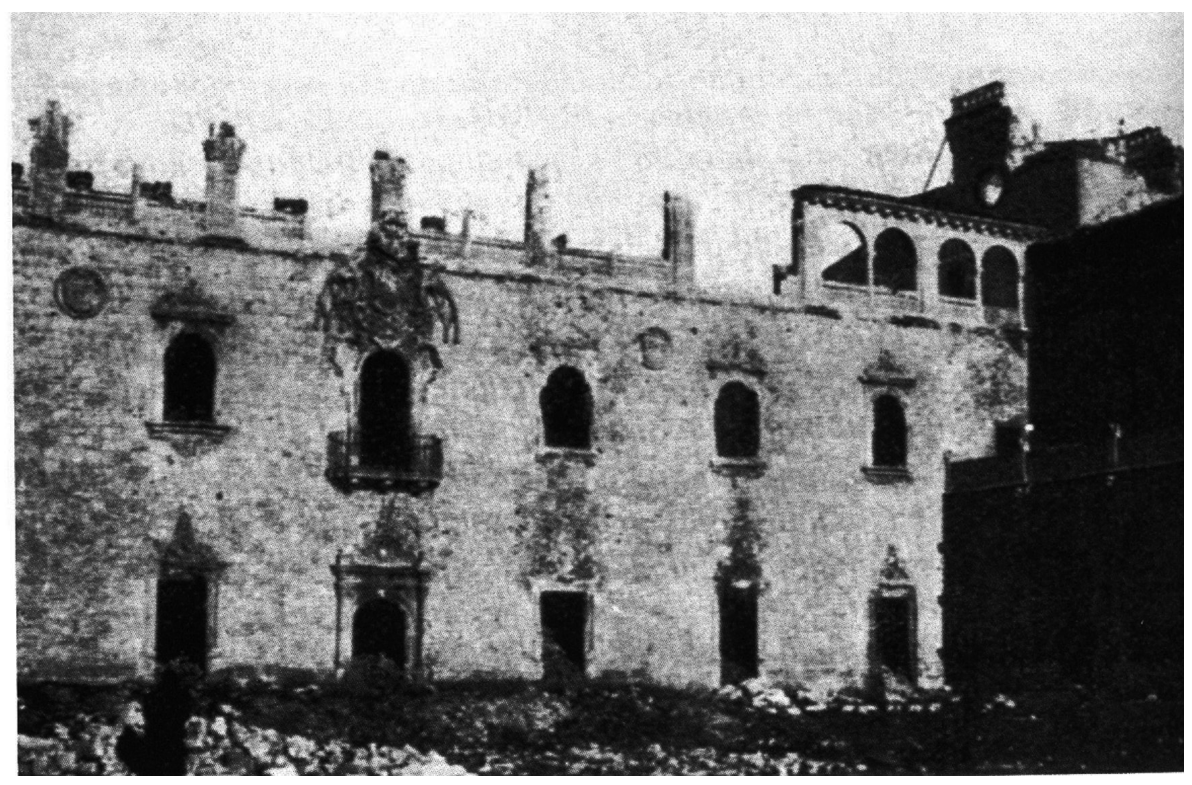

Figura 9. Patio de Armas tras el incendio (Foto publicada por Rodolfo García Pablos).

No obstante y al respecto, habría que señalar el contexto histórico en que ocurrió el incendio y destrucción del Palacio Arzobispal para «entender» en parte la incomprensible impunidad con la cual concluyó este trágico suceso para con el Arte, Historia y Memoria de nuestra nación y de la ciudad de Alcalá durante su Edad de Oro, pues se vivían los orígenes de la dictadura militar que prosiguió a la conflagración bélica, contemporáneo además con otro hecho de gran relevancia que obligaba a silenciar en la medida de lo posible la pérdida del monumento alcalaíno, para no obstaculizar la tramitación que estaba llevando a cabo el Gobierno Español para la devolución de las obras de arte mueble que custodiaba en Ginebra el Comité Internacional por el Salvamento de los Tesoros Artísticos de España de la Sociedad de Naciones durante la Guerra Civil.

38 LLULL PEÑALBA, J.: «La destrucción del patrimonio...», Op. Cit., pág. 204.; SAN LUCIANO, J. Mㄹ․: El incendio y destrucción..., Op. Cit., pág. 217. 
En cuanto a los restos del palacio que sobrevivieron al incendio, citar que de la crujía central se tenía en pie tan sólo la Fachada Plateresca, aunque su galería superior estaba casi totalmente destruida, no quedando ningún resto ni de las cubiertas ni de los interiores de la misma.

Del ala oriental o de Concilios solamente quedaban, además de sus muros perimetrales, en los cuales se apreciaban aún parte de las yeserías que los adornaban, los Torreones de Tenorio y del Ochavo, éste sin su característica cubierta.

Prácticamente toda la zona occidental, la más antigua del edificio, estaba destruida, quedando tan sólo en pie los restos de las crujías del Patio de la Fuente tras haberse derrumbado sus arquerías, además de la galería de nichos barroca; las ruinas de las contemporáneas construcciones noroccidentales ${ }^{39}$, con el desmochado Torreón del Archivo (Fig. 12); los muros del Ala de San Diego, habiéndose perdido su artesonado y demás joyas artísticas y documentales; las ruinas del Patio de Fonseca tras haberse hundido sus galerías, quedando entre sus escombros capiteles, fustes y otros elementos decorativos ${ }^{40}$, además de dejar en sus crujías norte y oriental dos grandes arcos mudéjares que debieron pertenecer al primitivo castillo medieval; los restos de la Escalera de Tavera, tras haberse desmoronado sus arquerías y balaustradas, conservándose en buen estado tanto el primer lienzo como gran parte de sus sillares almohadillados y portada adintelada; gran parte de las galerías del Ave María e igualmente la primitiva portada oriental del alcázar, con los torreones mudéjares y de la Fuente desmochados.

Casi dos años después del incendio, aún no se había realizado ninguna actuación sobre sus ruinas, poniendo de manifiesto la escasa consideración que se tuvo con tan preciado monumento. A partir de mayo de 1941, los arquitectos de la Dirección General de Bellas Artes, Rodríguez Cano y González Valcárcel, acometieron las obras más urgentes para impedir que continuase el saqueo de sus valiosas piezas artísticas, con el desescombro general de sus restos.

Como inciso, citar que en mayo de 1943 tuvo lugar la petición del Arzobispo de Madrid-Alcalá, Leopoldo Eijo Garay, para que le fuese revertida la posesión de los restos del palacio como antiguo propietario del mismo, al estar abandonados y ya no utilizados como archivo por el Estado, siendo aprobada en julio del mismo año.

A partir de mayo de 1944 y en los sucesivos años, los arquitectos García Pablos y de nuevo Cano y Valcárcel, iniciarían la restauración-reconstrucción de las zonas central y oriental del edificio ${ }^{41}$ para destinarlas a Seminario Menor de la Diócesis, conservando sus originales fachadas plateresca y neogótica-mudéjar y ha-

39 Y lugar donde se originó el fuego.

40 Que serían utilizados en años posteriores tanto en la restauración misma del palacio como en otras propiedades particulares de la ciudad, como por ejemplo en el Museo-Casa Natal de Cervantes.

41 Utilizando para ello, entre otros materiales, piedra procedente de la alcalaína Iglesia de Santa María, destruida también durante la Guerra Civil, ver en LLULL PEÑALBA, J.: «La destrucción del patrimonio...», Op. Cit., pág. 191. 
bilitando los antiguos Salones de Concilios y de Isabel la Católica como capilla y sala de actos, respectivamente. Por el contrario, se consideró irrecuperable el ala occidental con su consecuente abandono y demolición, conllevando a que en la actualidad tan sólo se conserve de esta zona el Torreón de la Fuente, e igualmente permanezcan en estado de ruina más de setenta años después algunos restos de la Fachada del Ave María, el Torreón del Archivo desmochado, algunos paredones de la crujía de San Diego, el cierre norte del Patio de la Fuente y los restos enterrados tras la explanación de todos estos terrenos de los solados y arranques de muros de sus antiguos claustros y salas anexas. Por último y a colación, añadir que en el Museo de la Catedral-Magistral de Alcalá se conservan un tercio de los sillares almohadillados de la Escalera de Honor de Tavera.

Estas obras merecieron numerosas críticas, a pesar de sentar la base para que hoy en día al menos se conserve y utilice parte del palacio, pues supusieron la pérdida de multitud de valiosos restos que habían sobrevivido al incendio, máxime teniendo en cuenta que las ruinas del mismo seguían protegidas legalmente como Monumento Nacional.

\section{UNA MIRADA AL PRESENTE}

\section{Restauración y rehabilitación como Palacio Arzobispal (siglos XX-XXI)}

En los cincuenta años transcurridos desde las primeras intervenciones de restauración en los años 40 hasta la gran rehabilitación de los años 90 , se sucedieron los intentos de recuperación del palacio con el ya citado Seminario, pasando por otras ideas no materializadas como parque, Museo Arqueológico, escuelas públicas... Todos fracasaron por la gran complejidad de este conjunto al contener ruinas sin excavar, documentación sin estudiar, falta de planeamiento urbanístico y su dimensión, que obligaba a un proyecto integral difícil de acometer en su totalidad, explicando con ello su semiabandono. Las necesidades funcionales del nuevo Arzobispado de Alcalá, constituido el 23 de julio de 1991 bajo la prelatura de Manuel Ureña Pastor, imprimieron un gran avance en materias de planeamiento, documentación, arqueología y rehabilitación para albergar en él nuevamente la sede episcopal, recuperando su pasado definiendo las líneas que marcarían su futuro.

En 1993 la comisión técnica realizó, tal y como determinaba el Plan Especial de Protección, un estudio sobre los volúmenes y el impacto visual que el palacio tuvo en el perfil de la ciudad a lo largo de su historia, con la conclusión de no recuperar su aspecto original a pesar del gran número de elementos arqueológicos encontrados, dada la dificultad de la reintegración con una anastilosis obligada en muchas de sus zonas. Por lo tanto, los restos de la Escalera de Tavera, el Patio de Fonseca, la Fachada del Ave María y las ampliaciones del siglo XIX serían objeto de un proyecto enfocado hacia la consolidación de sus ruinas como jardines arqueológi- 
cos, con la posible construcción de varios nuevos edificios en torno a los patios del Archivo y de la Fuente ${ }^{42}$, y de un gran parque en la albacara amurallada (Fig. 14).

Por consiguiente, la intervención de la década de los 90 casi no incidió en los restos originales del palacio, centrándose más bien en las actuaciones que se realizaron en los años 40, 50 y 60, procediendo a la restauración general de cubiertas, fachadas e interiores, previo estudio y documentación de los historiadores Basilio Pavón y María José Arnaiz. El ala central se rehabilitó como zona administrativa, Curia de Gobierno, Residencia Arzobispal, Delegaciones Diocesanas y Biblioteca; en el ala oriental se reacondicionaron los ya existentes salón de actos y capilla del antiguo Seminario, habilitando en el Torreón del Ochavo el episcopologio o sala de retratos de los Obispos Complutenses ${ }^{43}$, realizados por el artista José María Larrondo; igualmente, se restauraron los antiguos Torreones de Tenorio y de la Fuente para albergar la Librería Diocesana y la Oficina de Viajes a Tierra Santa, respectivamente.

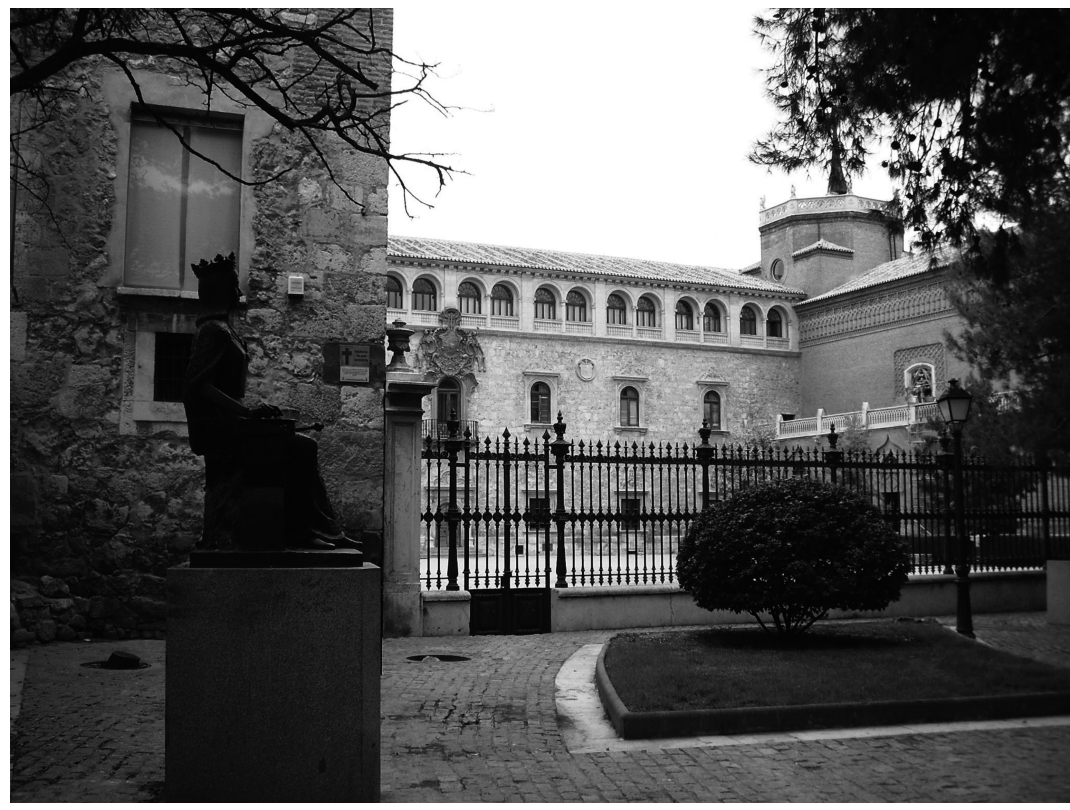

Figura 10. Palacio Arzobispal en la actualidad (Foto de Abraham Consuegra Gandullo).

En 1994, la Oficina Técnica del Obispado redactó un plan integral de conservación de las murallas, con una consolidación urgente en una treintena de puntos delicados en toda su extensión, reconstruyendo las zonas de tapial hundidas, con el retacado de ladrillos y remate de las zonas de coronación. Además, añadir que al

42 Los cuales podrían haber albergado, si la propuesta hubiese tenido viabilidad económica, el Parador Nacional de Alcalá de Henares, ubicado hoy en el antiguo Colegio-Convento Universitario de Santo Tomás de Aquino.

${ }^{43}$ Que han gobernado y gobernarán en el futuro la Diócesis Complutense, siguiendo la tradición de la mayoría de los Obispados españoles. 
Alcázar-Palacio Arzobispal de Alcalá de Henares: pasado, presente y futuro...

amparo de estas intervenciones, se procedió a su embellecimiento gracias a la iniciativa del escultor Pepe Noja, con la creación del aledaño Museo de Esculturas al Aire Libre de Alcalá de Henares, considerado como el más grande de Europa en su género. Sin embargo, como ejemplo de mala actuación y utilización del recinto murado, citar la instalación a finales de los años 90 de un aparcamiento público en superficie en el Pico del Obispo o antiguo Jardín de la Noguera.

Igualmente, se procedió al sondeo y estudio de los restos arqueológicos del antiguo alcázar y su huerta bajo la dirección de la arqueóloga Ana Lucía Sánchez, encontrando entre otros muchos elementos que se han podido conservar enterrados en el subsuelo del lugar, sus solados y empedrados de planta baja, el arranque de los muros de sus crujías y de las columnas de sus claustros, canalizaciones de época medieval ${ }^{44} \ldots$

Y ya en el presente siglo XXI, bajo titularidad municipal del recinto amurallado, y contemporánea a las prelaturas de los arzobispos Jesús Catalá Ibáñez (1999-2008) y Juan Antonio Reig Plá (2009-Actualidad), señalar la intervención de Arqueometría o «radiografía arqueológica» llevada a cabo en el año 2002 en el subsuelo de la Huerta del Obispo o Albacara a cargo de Alain Kermorvant, experto en Geofísica de la Universidad de Tours (Francia), revelando la existencia de los cimientos de un gran edificio medieval relacionado con la defensa del tramo sur de la muralla.

Por otra parte durante los años 2006 y 2007, se procedió al acondicionamiento de parte de los edificios y calles aledañas al Palacio Arzobispal, con la peatonalización de la calle San Bernardo y la regeneración ambiental del entorno de la Puerta de Madrid ${ }^{45}$ (Fig. 6).

En 2009 se intervino en la Puerta de Burgos, con su consolidación y reconstrucción mediante una anastilosis tras su derrumbe parcial del 13 de diciembre de 2005 , como consecuencia de su falta de mantenimiento, incidiendo en la importancia del suceso por la condición de Patrimonio de la Humanidad que tiene la ciudad de Alcalá de Henares.

Igualmente, se ha actuado en el resto del recinto amurallado a través del Taller de Empleo de Recuperación de las Murallas de Alcalá ${ }^{46}$ desde el año 2005 hasta la actualidad, con la puesta en valor de parte del espacio interior de la huerta con acceso por la recuperada Puerta de la Albacara, la cual se encontraba tapiada desde el siglo XIX, consolidándolo como un espacio turístico y monumental mediante su conservación, rehabilitación y musealización con la reciente inauguración ${ }^{47}$ en su

${ }^{44}$ Que nos aportarían la posibilidad de revisar las teorías tradicionales sobre el caótico urbanismo del medievo, ver en ARNAIZ GORROÑO, Ma․ J.; PAVÓN MALDONADO, B.; y otros.: «Arte, arquitectura y...», Op. Cit., pág. 256.

45 Uno de los monumentos más simbólicos de la ciudad de Alcalá de Henares.

46 Siendo éste un proyecto de formación promovido por el Ayuntamiento de Alcalá de Henares y subvencionado por la Comunidad de Madrid, el Ministerio de Cultura y el Fondo Social Europeo.

47 El 2 de diciembre de 2010, con motivo del XII aniversario de la declaración de Alcalá de Henares como Ciudad Patrimonio de la Humanidad. 
tramo sur del Paseo Arqueológico ${ }^{48}$, del Antiquarium ${ }^{49}$ y de una excavación arqueológica ${ }^{50}$, todo ello con su correspondiente interpretación mediante paneles informativos (Fig. 11).

Añadir además, que la anterior intervención es un ejemplo evidente de cómo se puede conciliar la conservación del patrimonio cultural con el respeto a la avifauna que lo habita, mediante la adecuación de los mechinales de sus torreones con unas placas especiales, permitiendo la nidificación del Cernícalo Primilla ${ }^{51}$, pequeña rapaz en peligro de extinción. A colación, indicar que el recinto cuenta igualmente con la presencia de la emblemática Cigüeña Blanca, uno de los símbolos más representativos de Alcalá52, señalando al respecto la existencia de un itinerario turístico denominado «La Ruta de las Cigüeñas» que ofrece una excelente forma de conocer la ciudad al combinar el legado histórico con el natural, debido al asentamiento de estas aves en sus principales monumentos.

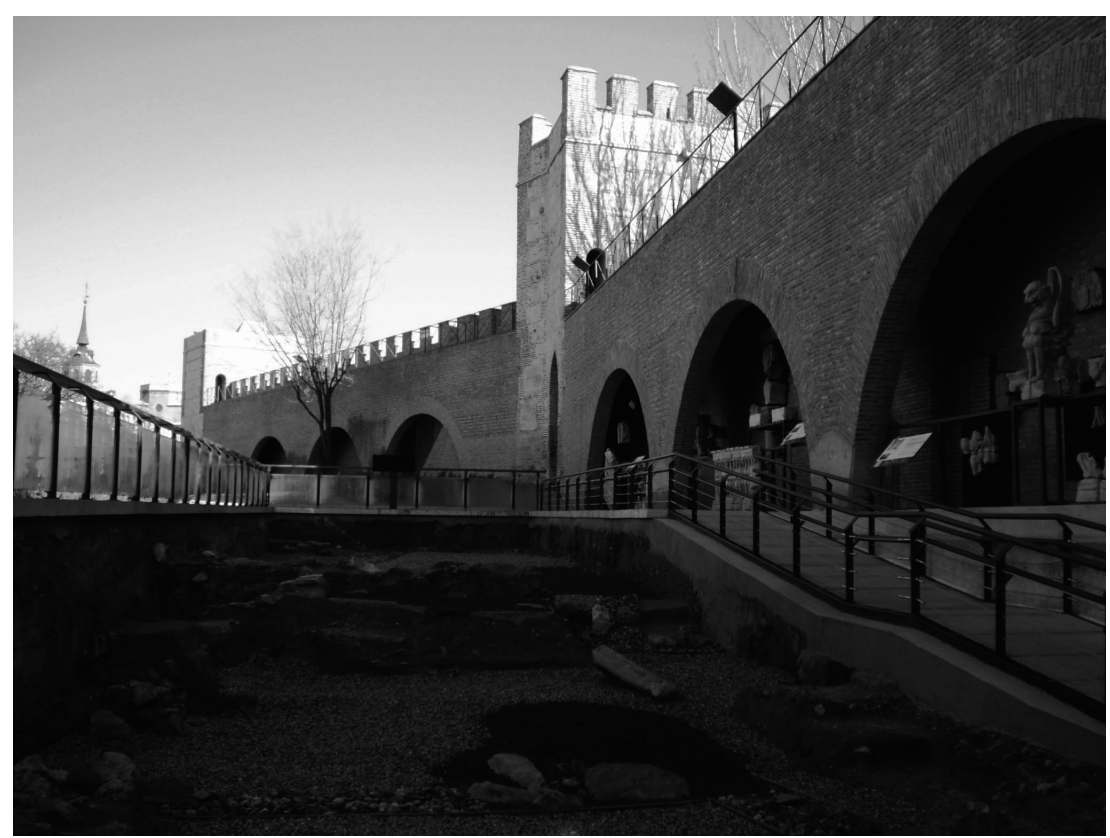

Figura 11. Muralla, Antiquarium y paseo arqueológico (Foto de Abraham Consuegra Gandullo).

48 Camino de ronda que permite acceder al adarve de la muralla y parte alta de las torres.

49 Selección de piezas decorativas del antiguo palacio, expuestas en cada uno de los contextos de los que formaban parte originalmente, dícese Galerías del Ave María y del Aleluya, Patio de Armas y Ochavo, Claustro de Fonseca y Escalera de Honor de Tavera.

50 Con los restos de antiguos cuerpos de guardia, caballerizas y un camino de ronda interior empedrado, que nos hace revisar la teoría de una albacara diáfana y libre de edificaciones.

51 Con más de 19 parejas en el recinto arzobispal, significando la colonia urbana más importante de la Comunidad de Madrid.

52 Ya que es la tercera colonia urbana más grande de España tras Cáceres y Alfaro, existiendo más de 25 nidos entre las ruinas del palacio y el vecino Vulgo de Bernardas. 
Recientemente, se han acometido obras en el palacio conservado, subsanando las patologías por humedades de sus cubiertas y muros; losando el Patio de Armas, desconociendo si se han preservado los suelos y canalizaciones medievales que subyacen en el solar al desestimar su recuperación; y rehabilitando el Salón de Actos, el Patio del Aleluya y la Biblioteca Diocesana ${ }^{53}$. Citar que actualmente, se está procediendo al desescombro e inventario de sus ruinas y restos arqueológicos (Fig. 12).

Por último, destacar que las actuaciones realizadas en el Alcázar Arzobispal en las dos últimas décadas han ido de la mano del desarrollo de la última y más amplia norma en materia de salvaguarda y protección del legado cultural nacional se refiere, la Ley del Patrimonio Histórico Español ${ }^{54}$ de 1985, comparable en su contenido a la de los demás países europeos y desarrollados del mundo. Al abrigo de esta legislación ${ }^{55}$, se desarrolló en Alcalá de Henares una ingente actividad de conservación, restauración y rehabilitación monumental con la finalidad de recuperar su casco histórico de mano de la Universidad de Alcalá (1977) y del Arzobispado Complutense (1991), conllevando a su declaración como Ciudad Patrimonio de la Humanidad por la Unesco el 2 de diciembre de 1998.

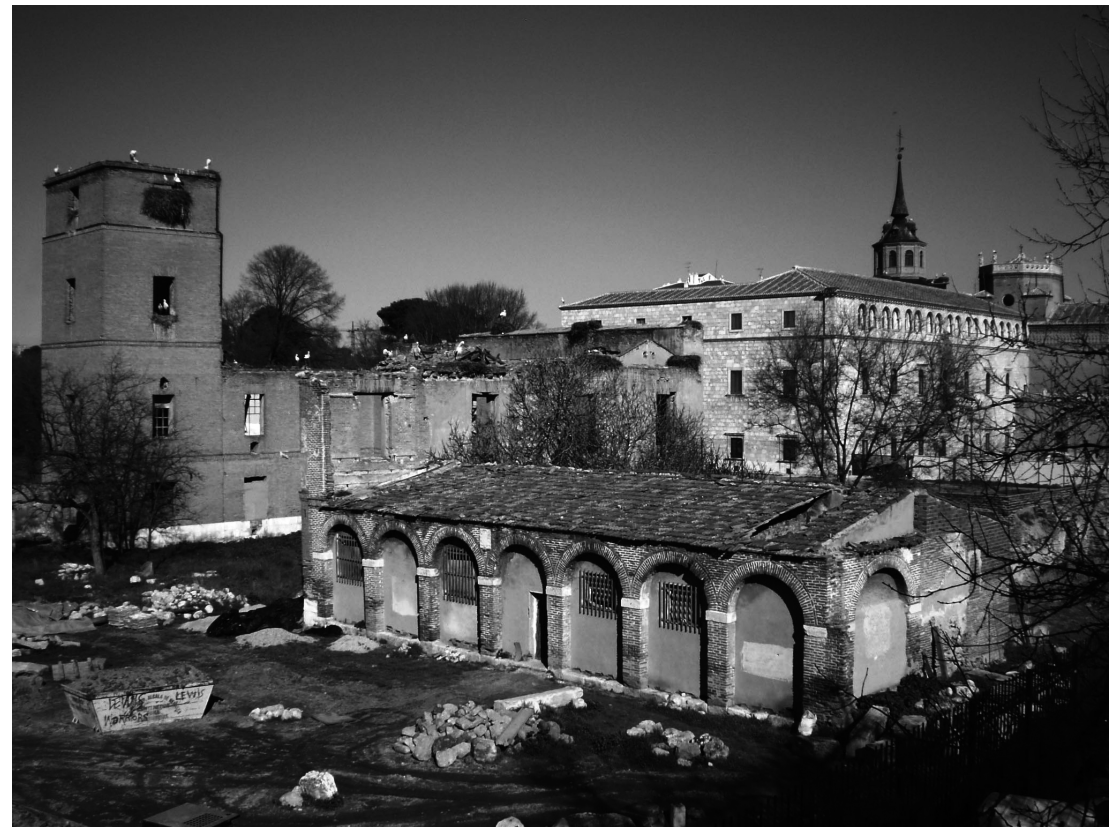

Figura 12. Palacio, ruinas y restos arqueológicos en la actualidad (Foto de Abraham Consuegra Gandullo).

53 Gracias al Convenio Palacio Arzobispal 2010 de la Dirección General de Patrimonio Histórico de la Comunidad de Madrid.

54 GONZÁLEZ-VARAS IBÁÑEZ, I.: Conservación de bienes culturales: teoría..., Op. Cit., pág. 517.

55 Además de diversas leyes autonómicas y municipales, consultar en la Comunidad de Madrid y en el Ayuntamiento de Alcalá de Henares. 


\section{UNA MIRADA AL FUTURO}

\section{Ideas de futuro para el Alcázar Arzobispal de Alcalá (Siglo XXI)}

Con vistas al futuro, hay que perseverar en la labor de recuperación del recinto prelaticio en la misma línea de trabajo de los últimos años, basando las intervenciones de conservación, rehabilitación e interpretación monumental en la normativa legal vigente, teniendo en cuenta además que la presentación del patrimonio arqueológico «in situ» a través de la musealización de los yacimientos es una recomendación contenida en diversos documentos internacionales ${ }^{56}$, sirviendo como ejemplo de ello el desarrollado igualmente en la Ciudad Romana de Complutum en Alcalá de Henares.

Con las debidas inversiones, se podría desplegar todo el potencial que posee este conjunto monumental para la mejora de la calidad de vida del ciudadano/a y de la economía, con especial incidencia en la dinamización del sector turístico de la localidad. Contando con todas las ideas de los alcalaínos/as lograríamos el desarrollo sostenible de esta zona tan especial del casco histórico de Alcalá, pues el Palacio Arzobispal ha sido, es y debe de seguir siendo un referente en la vida cultural y social de nuestra ciudad. Mi idea personal, una más entre tantas y como idea base a compartir con otras, la desarrollo a continuación (Fig. 13).

Continuar con el adecentamiento y conservación general del palacio, actuando principalmente sobre las humedades de los muros del Ala de Concilios, interviniendo en la misma línea de trabajo en el vecino Monasterio de San Bernardo, que si bien alberga el Museo de Clausura Religiosa y ocasionalmente su iglesia está abierta al culto, el resto del cenobio incluida su huerta, se encuentra en un estado alarmante de semiabandono ${ }^{57}$. Como la práctica nos ha demostrado, no hay mejor forma de conservar un monumento que con su apropiada reutilización.

Posible restauración y rehabilitación de las ruinas del antiguo Palacio, sitas a poniente del mismo, para albergar el Museo-Centro de Interpretación del Alcázar Arzobispal de Alcalá, con un programa museográfico compuesto por exposiciones permanentes basadas en maquetas e imágenes virtuales de cómo fue el monumento en sus diferentes épocas ${ }^{58}$ (Figs. 5, 8 y 13), fotografías, documentos históricos, maquetas físicas, paneles explicativos, restos arqueológicos... además de exposiciones temporales, ciclos de conferencias y visionado de audiovisuales sobre su arquitectura, historia... acondicionando, en el mismo lugar donde se situaba el

56 Como la Carta Internacional para la Gestión del Patrimonio Arqueológico (ICOMOS, 1990) y el Convenio Europeo para la Protección del Patrimonio Arqueológico (La Valette, 1992), ver en GONZÁLEZVARAS IBÁÑEZ, I.: Conservación de bienes culturales: teoría... Op. Cit., pág. 517.

57 LLULL PEÑALBA, J.: «La destrucción del patrimonio...», Op. Cit., pág. 419.

58 Sirvan como humilde ejemplo las figuras 5, 8 y 13 adjuntas a este artículo. 
antiguo Salón de San Diego, el denominado "Mirador de América» ${ }^{59}$ como belvedere turístico sobre el palacio y sus patios musealizados, y el hoy ruinoso Torreón del Archivo como mirador elevado sobre el Parque de la Albacara y su recinto murado $^{60}$.

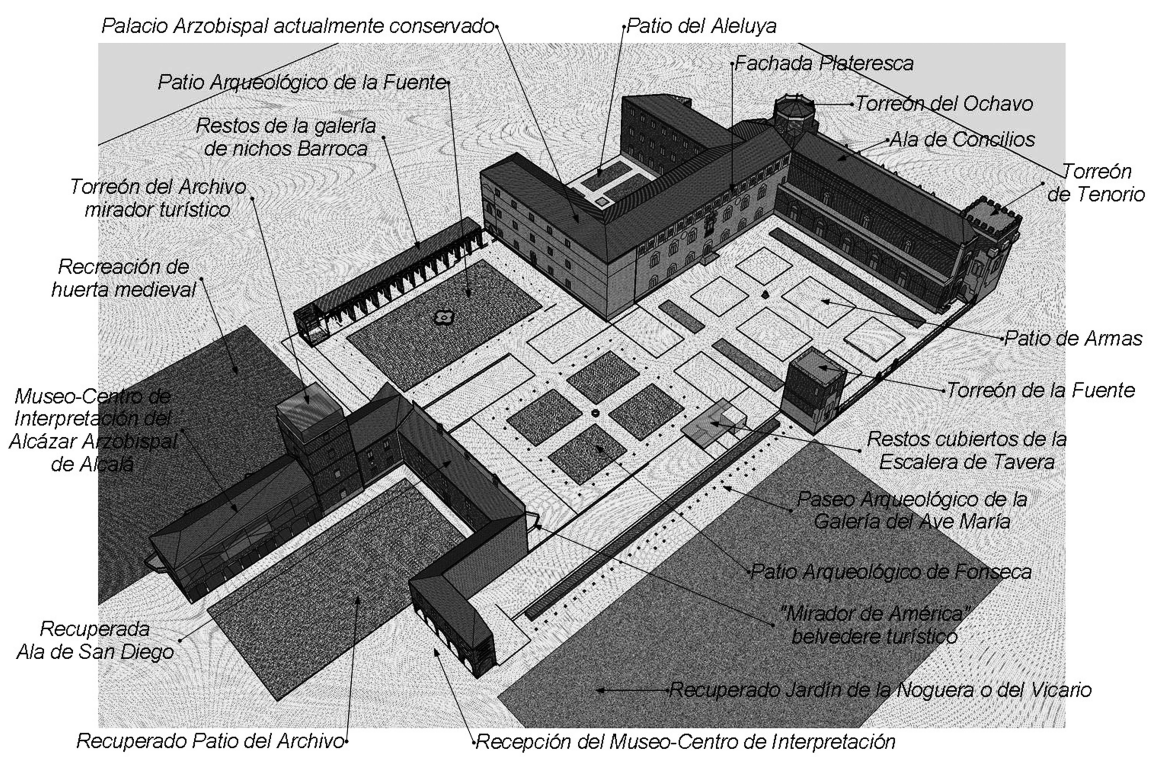

Figura 13. Recreación virtual del posible futuro del palacio (Dibujo-proyecto de Abraham Consuegra Gandullo).

Posible excavación, consolidación, interpretación y musealización de los restos arqueológicos que subyacen hoy día entre el Palacio y las ruinas del mismo, con un itinerario turístico por el yacimiento como continuación de la visita al museo. Discurriría por el Jardín de la Noguera, siendo recuperado con su antigua traza renacentista-barroca ${ }^{61}$, para lo cual se eliminaría el aparcamiento público en superficie situado en estos momentos en el lugar (sustituido por un parking subterréneo bajo el subsuelo de la Huerta del Obispo); por la Galería del Ave María, con un paseo entre los restos de las pilastras de sus antiguas arquerías dando paso al Patio Arqueológico de Fonseca, donde se admirarían sus empedrados-enlosados originales, los arranques de las columnas de su claustro y los restos debidamente protegidos de la Escalera de Tavera, que mediante una anastilosis podrían ser de nuevo emplazados en su pretérita ubicación en la esquina sureste del patio, tras

59 Por ser en el Palacio donde comenzó a fraguarse el Descubrimiento del Nuevo Mundo al albergar la ya citada entrevista entre Isabel la Católica y Colón.

60 A semejanza de las recientes rehabilitaciones como miradores turísticos de las torres de Santa María y de la Catedral-Magistral sitas en las alcalaínas plazas de Cervantes y de los Santos Niños, respectivamente.

61 De la que se conserva hoy en día abundante documentación, consultar en el Archivo General de la Administración y en el Archivo Municipal, ambos sitios en Alcalá de Henares. 
ser correctamente transportados desde el Museo de la Catedral Magistral de Alcalá; por el Patio Arqueológico de la Fuente, visitando sus primitivos solados, las basas de sus columnas y los restos de la pila-fuente que le daba nombre; al oeste del anterior y a modo de recreación museística, se podría recuperar una antigua zona de huerta medieval como la que existió en su día en el palacio, restaurando para ello los aljibes y canalizaciones sitos en esta zona, así como con la reconstrucción de una típica noria agrícola. Todo el recorrido anteriormente descrito, estaría jalonado por diversos paneles informativos para la correcta interpretación de cada una de las partes que compondrían el parque arqueológico (Fig. 13).

A corto-medio plazo, se debería de continuar con la musealización de la muralla como medida directa de protección del patrimonio arqueológico, arquitectónico, natural y etnográfico, habilitando sus torreones como oficinas de turismo, salas de exposiciones y proyección de audiovisuales, librerías y bibliotecas, salones-café con encanto, tiendas de gastronomía y artesanía, miradores-observatorios de la avifauna urbana...

Proseguir igualmente con el ajardinamiento de la Huerta del Obispo mediante la creación del Gran Parque-Salón de la Albacara, combinando para ello la conservación de las arboledas hoy existentes con la plantación de nuevos ejemplares lejos de la muralla para facilitar su contemplación sin que a la vez las raíces, troncos y ramas afecten a la estructura de la misma; desaconsejar su implantación a base de praderas de césped, pues pese a resultar muy gratas a la vista, acaban afectando a los monumentos a su alrededor con patologías por humedades debido a las grandes necesidades hídricas que necesitan para su correcto mantenimiento, sugiriendo la utilización de arbustos y plantas aromáticas más adaptadas a la climatología y suelos de Alcalá; proceder a su riego a través de albercas y estanques de pluviales para la reutilización directa de aguas de lluvia y reciclada, contribuyendo así a la sostenibilidad medioambiental del conjunto; y para su diseño y ornamentación, se trazarían diferentes paseos y parterres jalonados de fuentes y esculturas pertenecientes a la posible ampliación del aledaño Museo de Esculturas al Aire Libre, además de bancos corridos, zonas de merenderos-cenadores, instalaciones deportivas y áreas infantiles, baños públicos... (Fig. 14).

Citar a colación que, desde hace muchos años, la albacara arzobispal es utilizada como lugar de celebración de conciertos, funciones de teatro y otros actos multitudinarios ${ }^{62}$, haciéndose necesaria la regulación de estos usos para evitar daños y alteraciones en el patrimonio del recinto, mediante la correcta ubicación de escenarios, quioscos de música y otras infraestructuras efímeras que canalicen los grandes movimientos de masas que acuden a estos acontecimientos. Para ello, propongo la creación del Centro Multiescénico del Alcázar Arzobispal de Alcalá, integrado por una gran explanada multiusos para albergar grandes espectáculos pú-

62 Siendo de los más importantes la representación anual de teatro al aire libre del «Don Juan Tenorio de Alcalá» o los conciertos estivales de las «Ferias por San Bartolomé». 
blicos, por un pequeño teatro para acoger representaciones culturales de diversa índole, además de la utilización de los Patios de Armas y del Aleluya actualmente conservados y de los posibles futuros Patios Arqueológicos de Fonseca, de la Fuente y del Archivo como áreas escénicas y expositivas, combinando arquitectura, arqueología, escultura y naturaleza en un mismo y polivalente espacio.

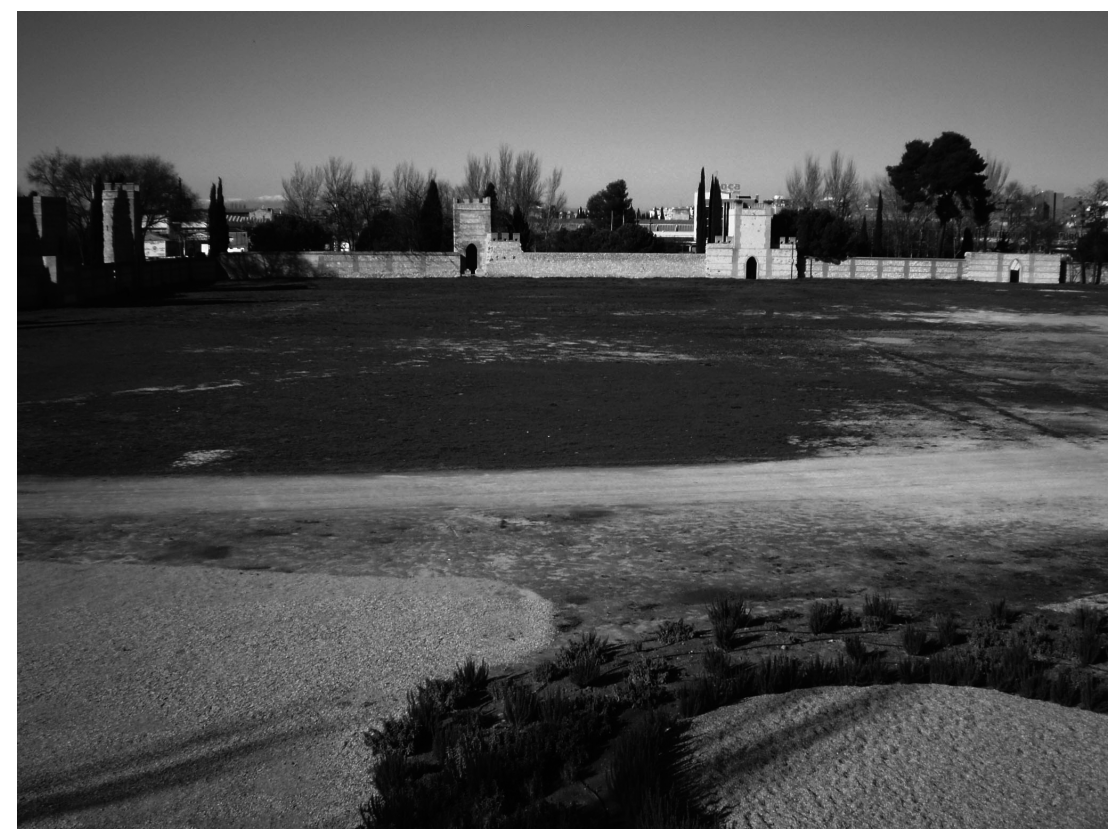

Figura 14. Posible futuro Gran Parque-Salón de la Albacara (Foto de Abraham Consuegra Gandullo).

Con vistas a corto-medio plazo, se debería de continuar con el adecentamiento de los edificios y calles limítrofes al recinto prelaticio, con la sustitución de su asfalto por un adoquinado más acorde con la imagen del casco histórico complutense, eliminando los aparcamientos en superficie y reduciendo el tráfico de vehículos a motor, en directo beneficio y uso para el peatón-ciclista.

Igualmente y con vistas a largo plazo, dada su dificultad y alto coste, proponer el soterramiento de la Vía Complutense ${ }^{63}$ en su tramo contiguo al palacio, puesto que hoy en día es poco más que lugar de paso, a pesar de la gran belleza de su muralla, debido al gran ruido y peligro que supone el intenso tráfico rodado que canaliza esta avenida. Con esta intervención, se habilitaría un gran paseo-explanada para disfrute de peatones y ciclistas, consiguiendo enlazar el Parque O'Donnell64 con el posible nuevo Gran Parque-Salón de la Albacara, evitando además la emi-

63 Antigua Nacional II y hoy una de las principales arterias de la ciudad.

64 El espacio verde por excelencia e historia de Alcalá de Henares. 
sión directa de contaminación ambiental, mejorando con ello la correcta conservación del monumento en cuestión.

Para llevar a cabo todas estas actuaciones, volver a incidir en la necesidad de establecer un Plan Director que involucre a todas las administraciones, instituciones y organismos culturales y económicos en la tarea de proteger, conservar, rehabilitar y musealizar uno de los recintos histórico-artísticos más importantes de España, en la misma línea de trabajo marcada en las dos últimas décadas, aplicando para ello la normativa legal vigente al respecto.

\section{EPÍLOGO FINAL}

«El objetivo más importante y último de este trabajo es, enseñar y divulgar la grandeza artística del monumento en cuestión, de lo que ya no se puede ver in-situ pero existió, de lo que se ve y hay que conservar y cuidar, y de lo que aún se está por descubrir y poner en valor de una forma original, responsable y actual para uso, disfrute y pedagogía de quien lo mire y observe».

Abraham Consuegra Gandullo 